\title{
Histological Examination of Precious Corals from the Ryukyu Archipelago
}

\author{
Masanori Nonaka, ${ }^{1}$ Masaru Nakamura, ${ }^{2}$ Makoto Tsukahara, ${ }^{1}$ and James Davis Reimer $^{3}$ \\ ${ }^{1}$ Okinawa Churaumi Aquarium, 424 Ishikawa Motobu-Cho, Okinawa 905-0206, Japan \\ ${ }^{2}$ Sesoko Marine Laboratory, University of the Ryukyus, Sesoko Motobu-Cho, Okinawa 905-0206, Japan \\ ${ }^{3}$ Transdisciplinary Research Organization for Subtropical Island Studies, University of the Ryukyus, 1 Senbaru, Nishihara, \\ Okinawa 903-0213, Japan \\ Correspondence should be addressed to Masanori Nonaka, m_nonaka@kaiyouhaku.or.jp
}

Received 25 March 2012; Accepted 9 July 2012

Academic Editor: Garth L. Fletcher

Copyright ( $\odot 2012$ Masanori Nonaka et al. This is an open access article distributed under the Creative Commons Attribution License, which permits unrestricted use, distribution, and reproduction in any medium, provided the original work is properly cited.

In this paper we examined the histology of three commercially valuable species of precious corals (Paracorallium japonicum, Corallium elatius, and C. konojoi) from the Ryukyu Archipelago. In order to observe their inner structure, samples were thin sectioned and examined with a digital light microscope. Colonies of $C$. konojoi had thicker coenenchyme and larger autozooids than those of C. elatius and P. japonicum. The sclerites of the three species tended to be concentrated in the outer layers of coenenchyme. The gastric cavities of autozooids of all three species were found to be relatively empty. Some symbiotic polychates were observed in the axis of P. japonicum. As well, a zoanthid (Corallizoanthus tsukaharai) was often observed living on the coenenchyme surface of $P$. japonicum. It is hoped our observations will provide a good foundation of future study of Japanese Coralliidae corals.

\section{Introduction}

Species in the genera Corallium and Paracorallium (Subclass Octocorallia, Order Alcyonacea, Family Coralliidae) are well known for their red or pink skeletons that have been used since antiquity for ornament, medicine, talismans, and currency. Therefore, they have long been known as "precious corals." Precious corals have been harvested routinely from the Mediterranean Sea for at least 5,000 years and were taken even as long as 30,000 years ago or more. Products made from Corallium rubrum (Linnaeus, 1758) are recorded from a Stone Age monument approximately 25,000 years old in Germany [1], and precious corals and shells were found in ruins roughly 30,000 years old in Lausanne, Switzerland [2]. The first record of collecting precious coral in Japan is from 1812, when a fisherman found a precious coral entangled in his net off Muroto, Kochi Prefecture, and harvest continues to the present day in the Kochi, Kagoshima, and Okinawa regions. It is generally recognized that the biomass of precious corals has been decreased by over-fishing, but there is little information about the biology of species from Japanese waters.

Some taxonomical studies about Japanese species have been published [e.g., [3-11]]. Regarding biological information, Grigg [12], Kosuge [1], and Iwasaki and Suzuki [13] have presented growth data. Ueno et al. [14], Iwase [15], and Nonaka et al. [16] have reported on the raising of precious coral in aquaria. Recently, Iwasaki [17] edited a comprehensive publication on scientific, cultural, and historical perspectives of Coralliidae corals.

However, there have been no studies on the histology or anatomy of Japanese precious corals, except for work performed by Kishinouye [7, 8]. His "Sango no kenkyu (in Japanese)" and "Notes on the Natural History of Corals (same contents of former publication translated in English)" were the first and last publications describing the total biology of Japanese precious corals. This work has some comments on the anatomical features of three Japanese species, $P$. japonicum (Kishinouye, 1903), C. elatius (Ridley, 1882), and 
C. konojoi Kishinouye, 1903. Kishinouye found that autozooids and siphonozooids communicated with each other by vascular canals, siphonozooids had reproductive elements, and, therefore, reported that siphonozooids were not immature autozooids but a different organ that takes part in reproduction. Kishinouye also included drawings of sections of a colony of each of these species harvested from Japan. Outside of Japan, Lacaze-Duthiers [18] described the anatomy of C. rubrum (Mediterranean) and included drawings of a sectioned branch and of a polyp brooding larvae. Hickson [19] includes a diagram of a transverse section through a branch of $C$. reginae Hickson, 1905, from the Flores Sea, Indonesia. Grillo et al. [20] analyzed axis and sclerite formation in C. rubrum, including some micrographs of histological sections. Recently, Simpson and Watling [21] described two new species of Coralliidae with histological sections of C. bathyrubrum [21]. They dissected the specimens and showed that canals function in communication among the polyps [21]. Also recently, Debreuil et al. [22] showed cross-sections of axial skeletons with toluidine blue staining of C. rubrum, and also cross-sections of axes of Corallium species for comparison, C. secundum Dana, 1846 (from Hawaii), and two Japanese species: C. konojoi and $C$. elatius.

Octocorallia corals are divided into three systematic orders: Helioporacea (Blue coral), Alcyonacea (soft corals and sea fans), and Pennatulacea (sea pens) [23]. Order Alcyonacea is divided into five suborders: Protoalcyonaria, Alcyoniina, Scleraxonia, Holaxonia, and Calcaxonia. These suborders are delineated by the contents of their axial structure; suborders Protoalcyonaria and Alcyoniina have no axial skeleton; suborder Scleraxonia has axes with free axial sclerites; suborder Holaxonia has continuous solid axes without free axial sclerites with a hollow cross-chambered central core; suborder Calcaxonia has solid axes without free axial sclerites and without a central core $[23,24]$. There are some exceptions: Keroeididae with an axial sclerite despite belonging to suborder Holaxonia [25], and Keratoisdinae (Isididae) with a hollow central core despite belonging to suborder Calcaxonia [26]. Family Coralliidae belongs to order Alcyonacea, suborder Scleraxonia [23]. Muzik and Wainwright [27] showed diagrammatic sections of some specimens of Alcyonacea octocorals, including two sclerxonian species, Subergorgia suberosa (Pallas, 1766) and Melithaea ochracea (Linnaeus, 1758). As well, the Caribbean holaxonian species Plexaura homomalla (Esper, 1794) has had its anatomy and histology studied in detail, with 62 beautiful, exquisite drawings [28]. These works by Muzik and Wainwright [27] and by Bayer [28] are good for comparisons with the present study. A few publications have described the details of general gorgonian anatomy and include detailed drawings of diagrammatic sections (e.g., $[29,30])$.

Thus, currently only old and limited information about the histology and anatomy of species of Japanese Coralliidae exists. In this study, we aim to clarify the histological biology of Coralliidae from Japan and in particular the three commercial species of the Ryukyu Archipelago.

\section{Material and Methods}

2.1. Sampling. Samples were collected from the Ryukyu Archipelago, the southernmost region of Japan (Figure 1). In the northern part of the archipelago (south of Kagoshima Islands and including Amami Islands), specimens were collected by manned submarine at depths of approximately 100 to $300 \mathrm{~m}$. In the southern part of the archipelago (including Okinawa Island, Miyako, and Ishigaki Islands), specimens were collected by remotely operated vehicle (ROV). As collections were made by a private company seeking large colonies for commercial purposes, sampling was not random. Instead, large colonies were selectively harvested, and environmental data (depth, water temperature, type of substrate, approximate latitudes of the collecting locations) were recorded for the area immediate of the collection. From 4 June 2005 to 1 March 2006, 83 specimens were collected, and from 23 June 2007 to 1 September 2009, 105 specimens were collected. Environmental data and whole colony size (height, width, and holdfast diameters) were reported in a previous publication [31]. Samples were divided into valuable parts (base parts of colonies) and unvalued parts (broken tips of branches; up to $15 \mathrm{~cm}$ long). The former were used for commercial purposes, and the latter were preserved and examined in this study. All specimens (tips of branches) are preserved in the Okinawa Churaumi Aquarium collection.

2.2. Identifications. All samples were identified using accepted morphological characters, such as color, branching pattern, polyp arrangement and size, as well as sclerite shape and size. Colony color and branching pattern were examined from in situ or shipboard photographs with a scale. Polyp arrangement and details were observed and measured by light microscope. Sizes and shapes of sclerites were documented by light and scanning electronic microscopy. Specimen identification followed Ridley [3], Kishinouye [58], Bayer [9], Bayer and Cairns [10], Nonaka and Muzik [11], and Nonaka et al. [32]. In Japan, there are seven species in the family Coralliidae, six described by Kishinouye [4-8], and one species by Ridley [3]. In this study, we only examined species with commercial value; namely, $P$. japonicum, $C$. elatius, and C. konojoi.

2.3. Observation of Histological Sections, Coenenchyme Surface, and Sclerites into the Coenenchyme. The original specimens were preserved in pure ethanol as specimens were preserved for not only histological examinations, but also for other studies including molecular analyses. Small subsamples (approximately 10-20 $\mathrm{mm}$ long) for making sections were separated from original specimens and decalcified in Bouin's solution. The subsamples were embedded in paraffin. Tissues were then thin sectioned $(7 \mu \mathrm{m})$, mounted on slides, stained with hematoxylin and eosin. Prepared specimens were observed and photographs taken with a digital microscope (Keyence VHX). Bayer [28] and Muzik and Wainwright [27] were referred to during our microscopic observations. Diameter of both autozooids and siphonozooids, thickness of coenenchyme, etc., were measured using accessory software of the digital microscope. In serial sections of the same 


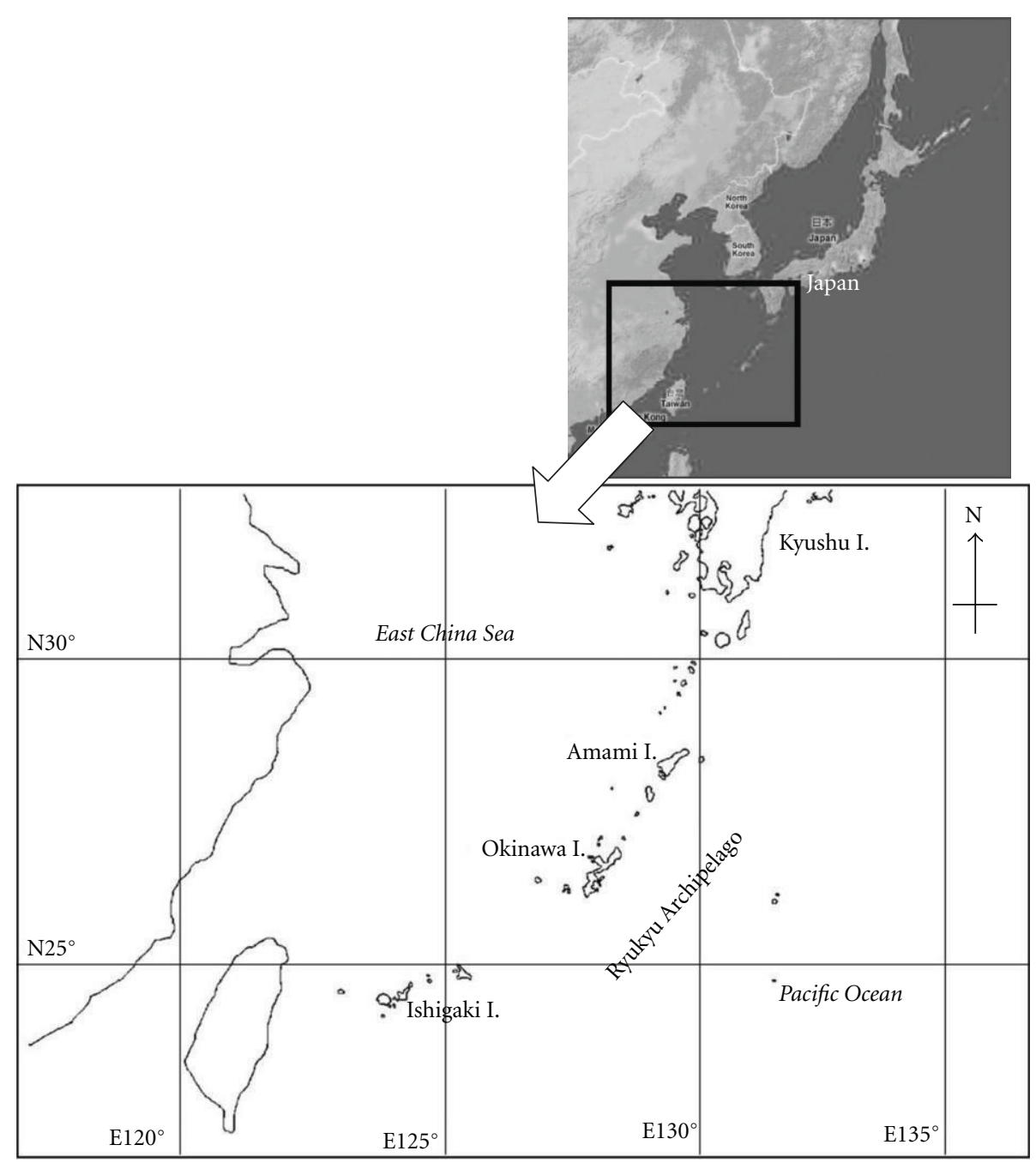

FIGURE 1: Map of precious coral sampling areas in southern Japan.

autozooid or siphonozooid, the largest measurement was selected as representing its actual size.

For supporting data, we also examined the surface details of samples (coenenchyme, polyps, axis, and sclerites) by scanning electronic microscope. To do so, sclerites and axes were separated and cleaned using 5\% sodium hypochlorite solution (household bleach). The examination was performed by a low-voltage type SEM (Keyence VE-8800).

The diagrams of the three species examined were drawn from images captured by digital microscope and scanning electronic microscope.

2.4. Data Analyses. The Student's $t$-test was used to analyze differences in coenenchyme thicknesses between anterior sides and posterior sides of each species. Statistical analyses were performed using MS Excel.

\section{Results}

3.1. Identifications. We identified 75 colonies as P. japonicum, 61 colonies as C. elatius, and 27 colonies as C. konojoi (Figure 2).
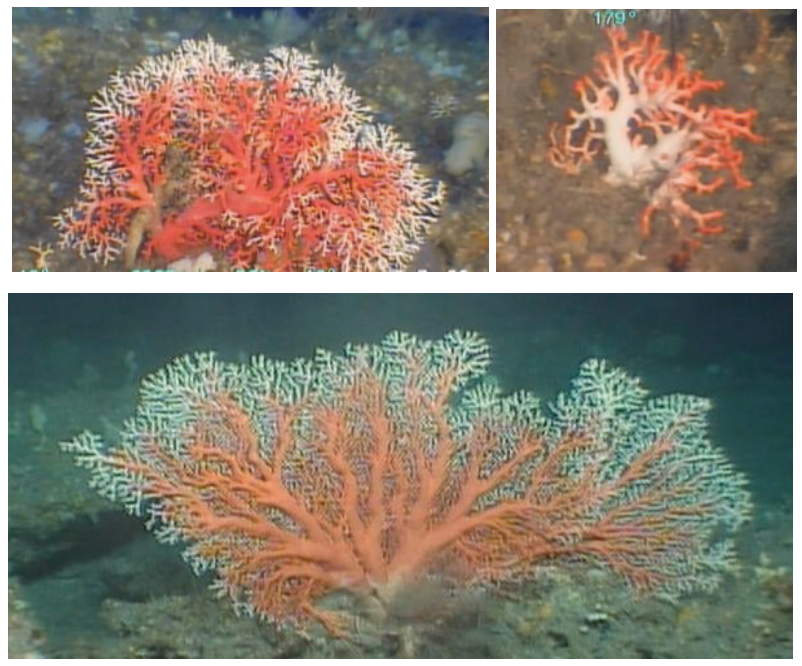

Figure 2: Commercial species of precious corals from Japan. Above left: Paracorallium japonicum (Kishinouye, 1903). Above right: Corallium konojoi Kishinouye, 1903. Below: Corallium elatius (Ridley, 1882). 


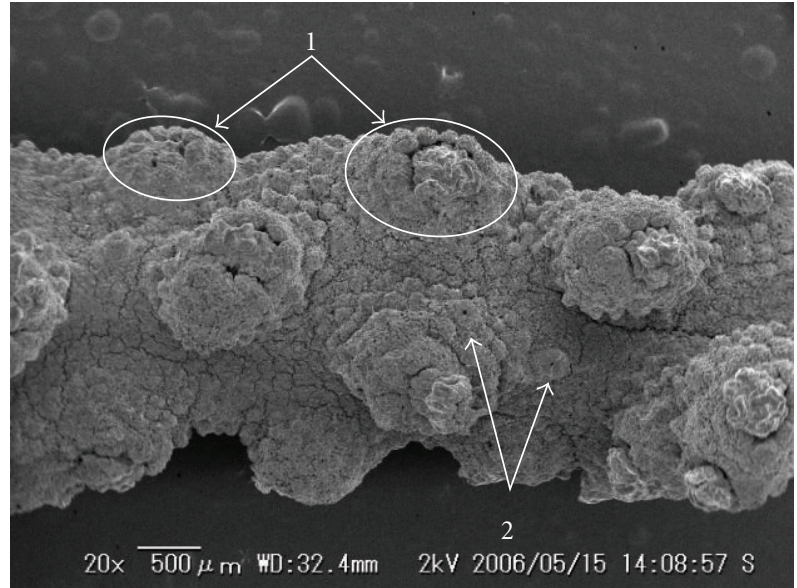

FIgURE 3: SEM image of coenenchyme surface of Paracorallium japonicum; OCA-Cn20060211-031. 1: coenenchymal mounds, 2: siphonozooid projections.

\subsection{Observation and Measurement of Histological Sections}

3.2.1. Paracorallium japocicum (Japanese Name: AkaSango). Specimens of this species had a rough coenenchyme surface (Figure 3), averaging $0.15 \mathrm{~mm}$ in thickness $( \pm 0.04 \mathrm{SD}, n=29)$, but the coenenchyme was somewhat thicker at the ends of twigs (Figure 4). Many warts (Figures 3,4 , and 5) were present on the coenenchyme surface, averaging $0.12 \mathrm{~mm}$ in height $( \pm 0.024 \mathrm{SD}, n=14)$. Many minute openings (Figure 5) were observed into the coenenchyme in histological sections, averaging $0.041 \mathrm{~mm}$ in diameter. There are some mesogloeal openings in the coenenchyme $[27,28]$, but the mesogloea was minute and made stippled pattern at this magnification (Figure 5). Sclerites of specimens were approximately $0.050 \mathrm{~mm}$ long in SEM examination (Figure 6). Therefore, we concluded that the openings were lacunae remaining after the decalcification of sclerites. The sclerites filling up the coenenchyme tended to be closer to the surface side (Figure 5). In transverse sections, larger openings (Figure 5) were more common than sclerites, and in longitudinal sections, these openings looked oval, elongate or formed longer "canals," averaging $0.078 \mathrm{~mm}$ in width $( \pm 0.022 \mathrm{SD}, n=11)$, and they were parallel with the axis (Figure 4; top). They joined with organizations of autozooids and siphonozooids, and they tended to be close to the axial side (Figures 4 and 5).

All autozooids were contracted in the specimens examined. Contracted autozooids were covered by a thin coenenchyme composed of many sclerites, which appeared mound-like on the surface (Figure 7). Recently, the term "coenenchymal mound" has been used in the description of Coralliidae [32, 33]. The coenenchymal mounds were almost uniform in shape and size (Figures 3 and 4). The diameter averaged $1.0 \mathrm{~mm}( \pm 0.12 \mathrm{SD}, n=45)$, and their height averaged $0.47 \mathrm{~mm}( \pm 0.11 \mathrm{SD}, n=35)$. In autozooids, there were tentacles, gastric cavities, muscular tissue, and mesenteries (Figure 7). Their gastric cavities were empty. In part of the tentacles, there were many minute openings

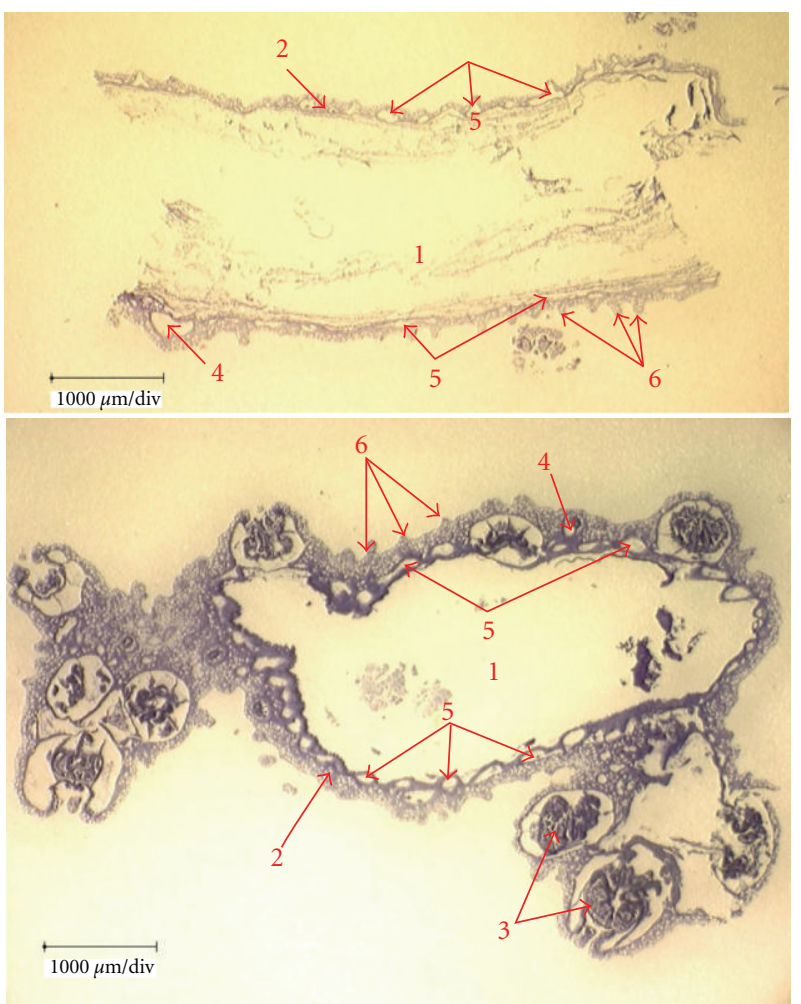

Figure 4: Histological sections of Paracorallium japonicum; longitudinal section in base part of OCA-Cn20080329-020 (above), and transverse section in branch tip of OCA-Cn20060212-033 (below). 1: axis, 2: coenenchyme, 3: autozooid, 4: siphonozooid, 5: vasucular canals, 6: wart.

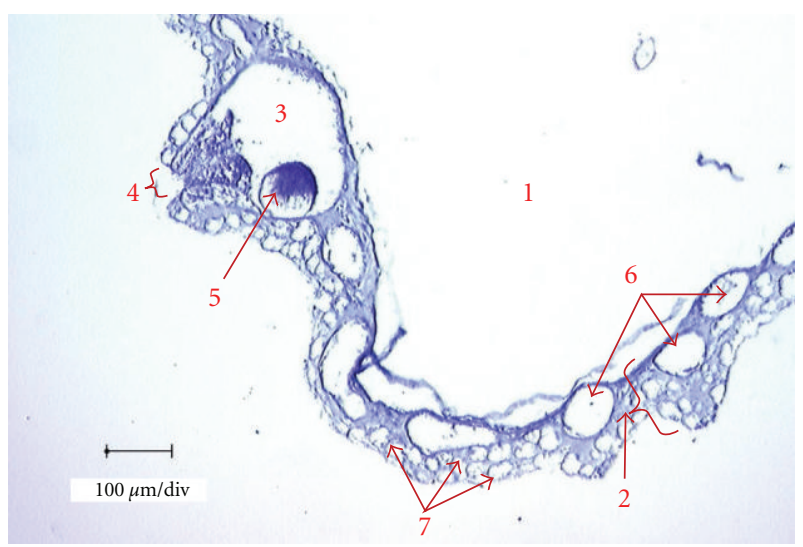

FIgure 5: Transverse section of Paracorallium japonicum; OCACn20080405-022. 1: axis, 2: coenenchyme, 3: siphonozooid, 4: siphonozooid opening, 5: gamete (oocyte), 6: vasucular canals, 7: lacunae of sclerite.

similar to as seen in the coenenchyme. These openings may have been the marks of sclerites (Figure 7).

Siphonozooids had undeveloped septa, and operculumlike structures inside of their openings. Openings were minute on the surface (Figure 5), and their diameter averaged $0.046 \mathrm{~mm}( \pm 0.016 \mathrm{SD}, n=43)$. Siphonozooids were of various shapes and size, with some forming "mounds" on the 


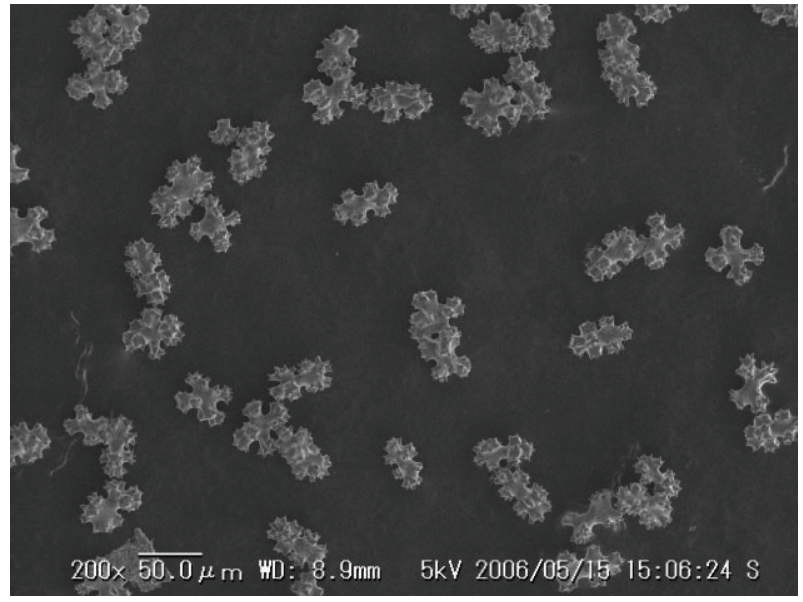

FIGURE 6: SEM image of sclerites of Paracorallium japonicum; OCACn20060211-031.

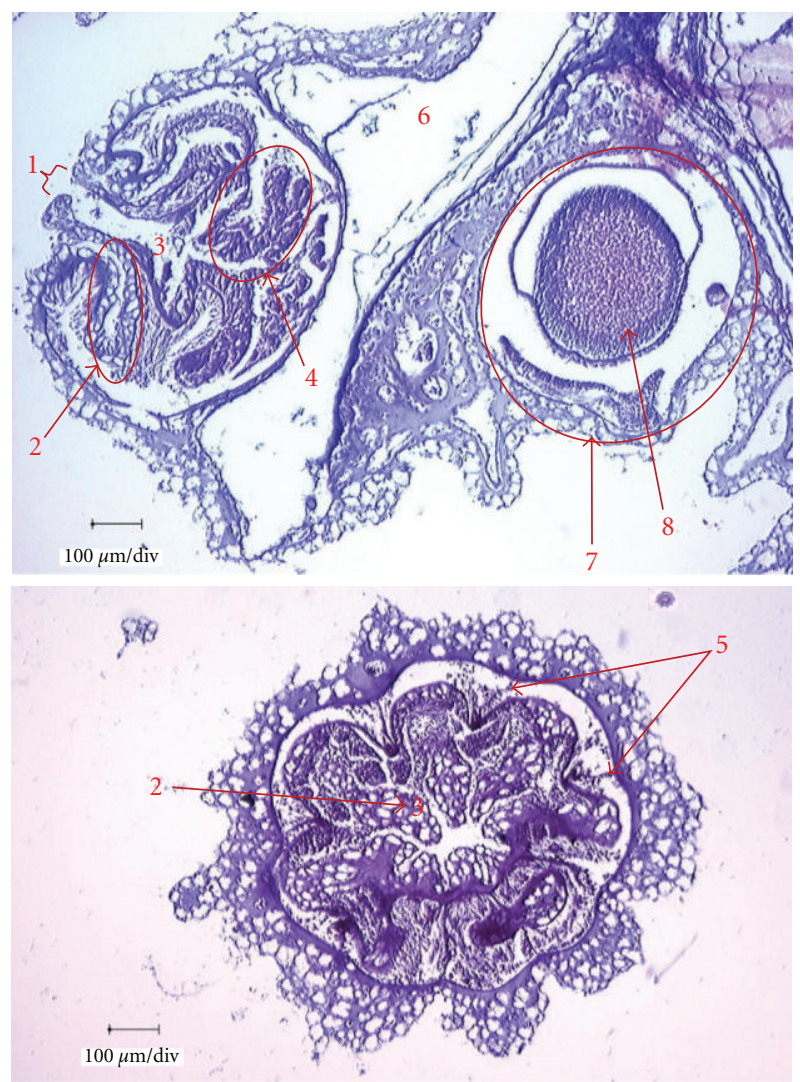

FIGURE 7: Longitudinal section (above; OCA-Cn20070908-007) and transversal section (below; OCA-Cn20051219-027) of autozooid of Paracorallium japonicum. 1: mouth opening, 2: tentacle, 3: gastric cavity, 4: muscular tissue, 5: septum, 6: axis, 7: siphonozooid, 8: gamete (oocyte).

surface (Figure 5), and some underneath autozooids (Figure 7; top). Some siphonozooids could not be distinguished from the canals in the transverse sections. In some specimens, siphonozooids become larger because they had differentiated gonads (Figures 5 and 7).
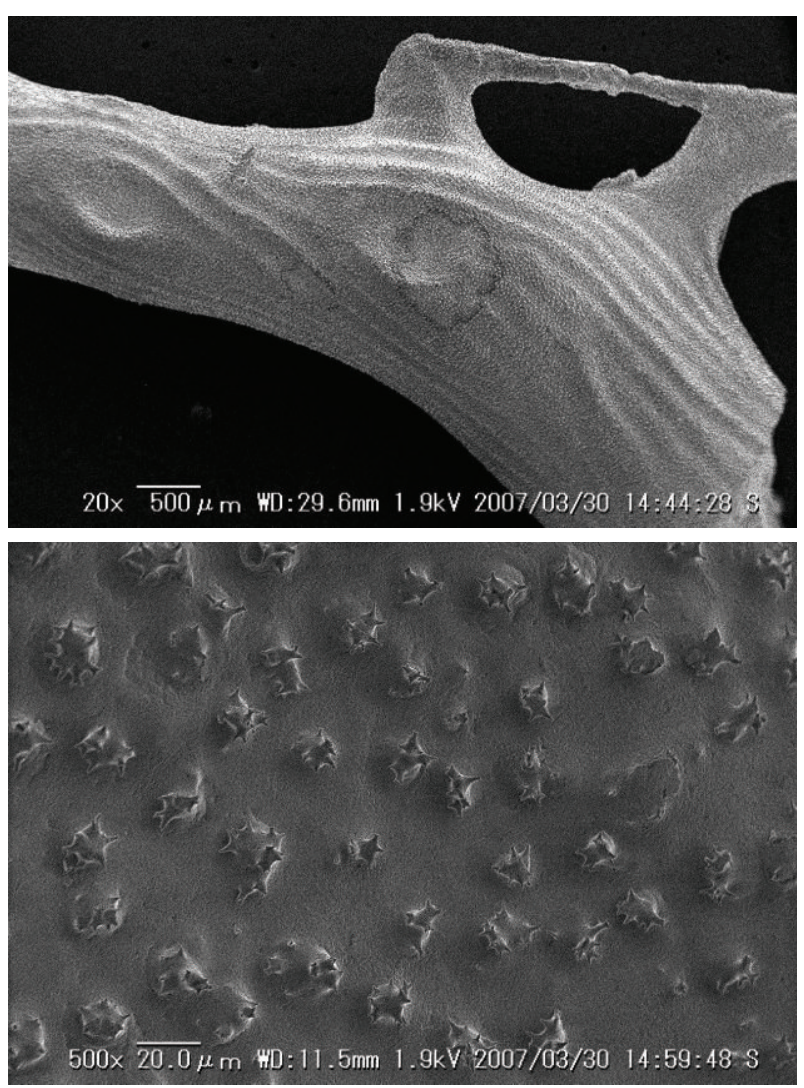

Figure 8: SEM image of axis surface of Paracorallium japonicum; OCA-Cn20051128-015.

The axial skeleton was decalcified and, therefore, appeared as a large gap at the center of the colonies in the prepared slides. Axial skeletons were oval or rounded in transverse sections (Figure 8), but irregularly shaped at the tip of the branches (Figure 4; bottom, Figure 9). In SEM examinations, the surface of axes was faintly longitudinally grooved (Figure 8; top), with grooves at intervals of an average of $0.171 \mathrm{~mm}$ apart $( \pm 0.045 \mathrm{SD}, n=26)$, and covered with minute tubercles ornamented with thorny projections (Figure 8; bottom). These axial grooves formed the canals in the coenenchyme (Figure 4; bottom). There were almost no pits underneath autozooids in our specimens. Some specimens were decalcified incompletely, and thus the axis structure was observable. Some rings were found around the center of the axis in transversal sections (Figure 9).

In 21 specimens, unknown commensal animals were observed embedded into the axis. These organisms resembled polychaetes as they had annular structures, and one individual had gonad-like structures in its body (Figure 10). These organisms inhabited a "nest hole" that appeared to either be bored through the host's axis, or the axis had secreted and grown around the commensals (Figure 11). On the surface of coenenchyme, we could find much larger, nonoctocorallian polyps growing on two specimens, with one of these specimens potentially harboring its own gonads (Figure 12). These polyps turned out to be zoanthids of the 


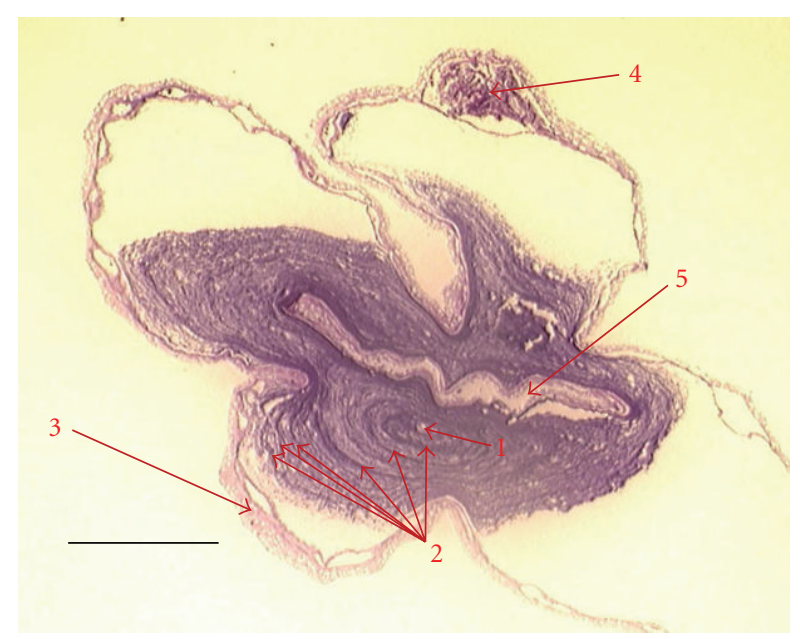

Figure 9: The transverse section of Paracorallium japonicum; OCA-Cn20090504-039. 1: center of the axis, 2: growth rings, 3: coenenchyme, 4: autozooid, 5: associated commensal. Scale bar is $1.0 \mathrm{~mm}$.

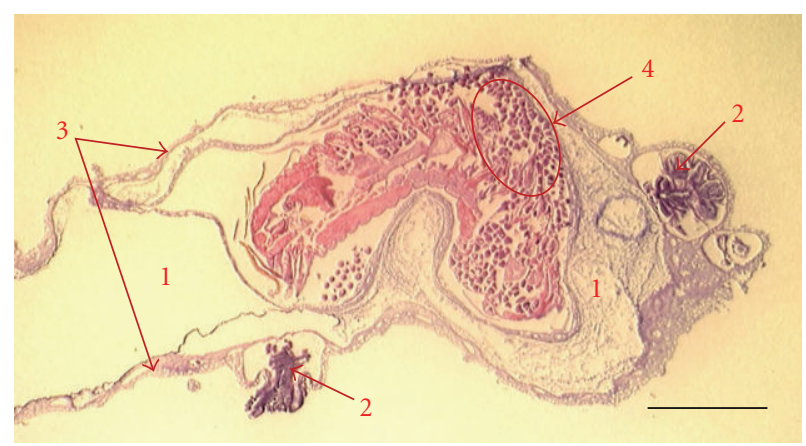

FIGURE 10: An unidentified commensal organism (possibly polychaete) with potential gonads associated into the axis of Paracorallium japonicum; OCA-Cn20090420-036. 1: axis, 2: autozooid, 3: gonads. Scale bar is $1.0 \mathrm{~mm}$.

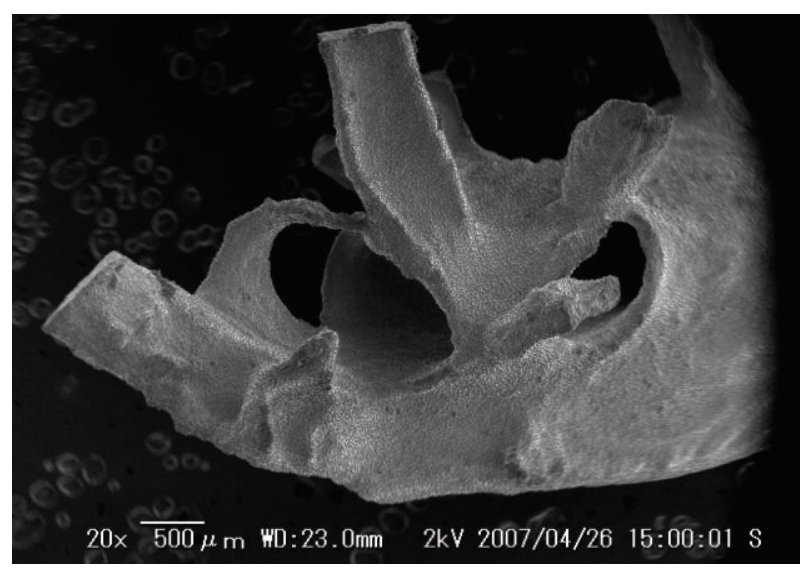

FIGURe 11: SEM image of Paracorallium japonicum with a commensal nest bored into the axis; OCA-Cn20051219-023.

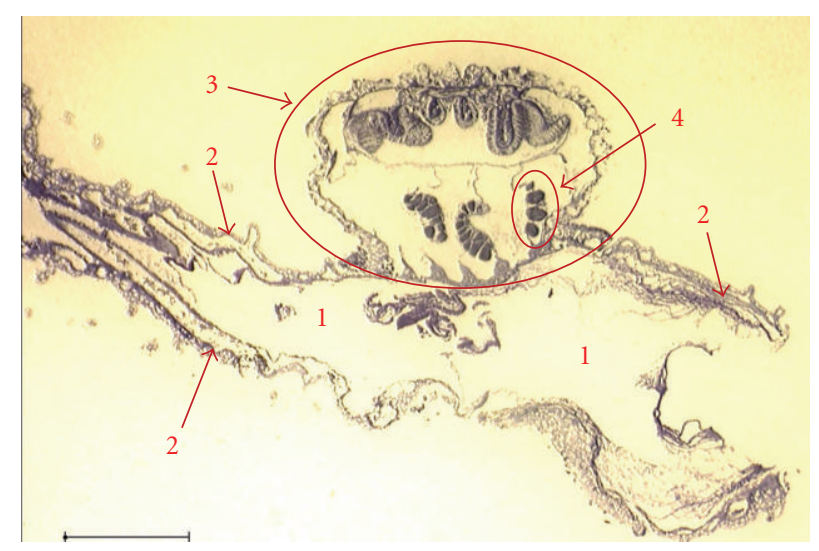

Figure 12: A section of Paracorallium japonicum; OCACn20060109-042 with a commensal zoanthid, Corallizoanthus tsukaharai. 1: host axis, 2: host coenenechyme, 3: polyp of commensal zoanthid, 4: gonads of commensal zoanthid. Scale bar is $1.0 \mathrm{~mm}$.

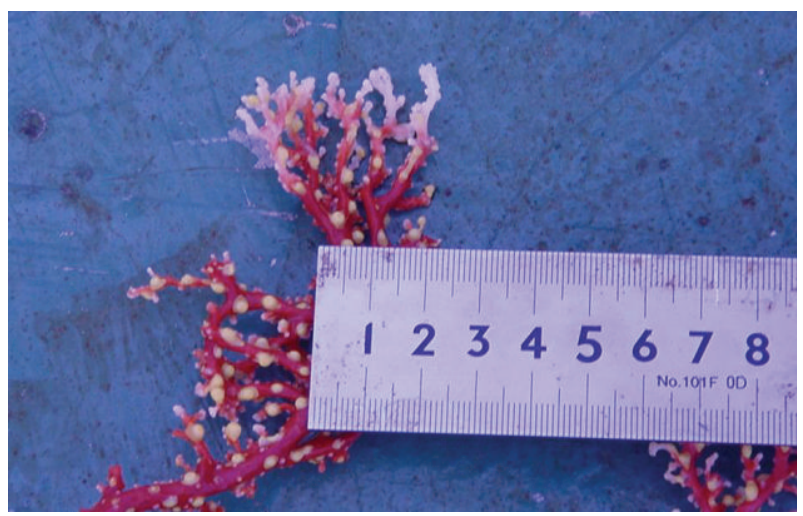

FIGURE 13: A commensal zoanthid (yellow in color), Corallizoanthus tsukaharai associated on the surface of Paracorallium japonicum; OCA-Cn20060109-042. The scale divisions are $1.0 \mathrm{~mm}$.

species, Corallizoanthus tsukaharai Reimer, 2008 (Figure 13) [34].

Figure 14 shows a diagram of $P$. japonicum drawn based on the results of these observation and measurements.

3.2.2. Corallium elatius (Japanese Name: Momoiro-Sango). This species had a rather smooth coenenchyme surface (Figure 15), averaging $0.51 \mathrm{~mm}$ in thickness $( \pm 0.16 \mathrm{SD}, n=$ 65 ), (Figure 16). The coenenchyme was thicker on the side with autozooids, averaging $0.54 \mathrm{~mm}$ in thickness $( \pm 0.16 \mathrm{SD}$, $n=37$ ), than on the posterior (without autozooids) side, averaging $0.47 \mathrm{~mm}$ in thickness $( \pm 0.15 \mathrm{SD}, n=28)$, but there was no significant differences $(t$-test, $P>0.05)$ between coenenchyme thicknesses of the two sides. Many minute openings were observed in the coenenchyme in the histological sections, approximately $0.06 \mathrm{~mm}$ in diameter (Figure 17). In SEM examination, sclerites of specimens were approximately $0.05-0.06 \mathrm{~mm}$ long (Figure 18 ), so we concluded that the openings were decalcified sclerites. The sclerites filling up the coenenchyme tended to concentrate 


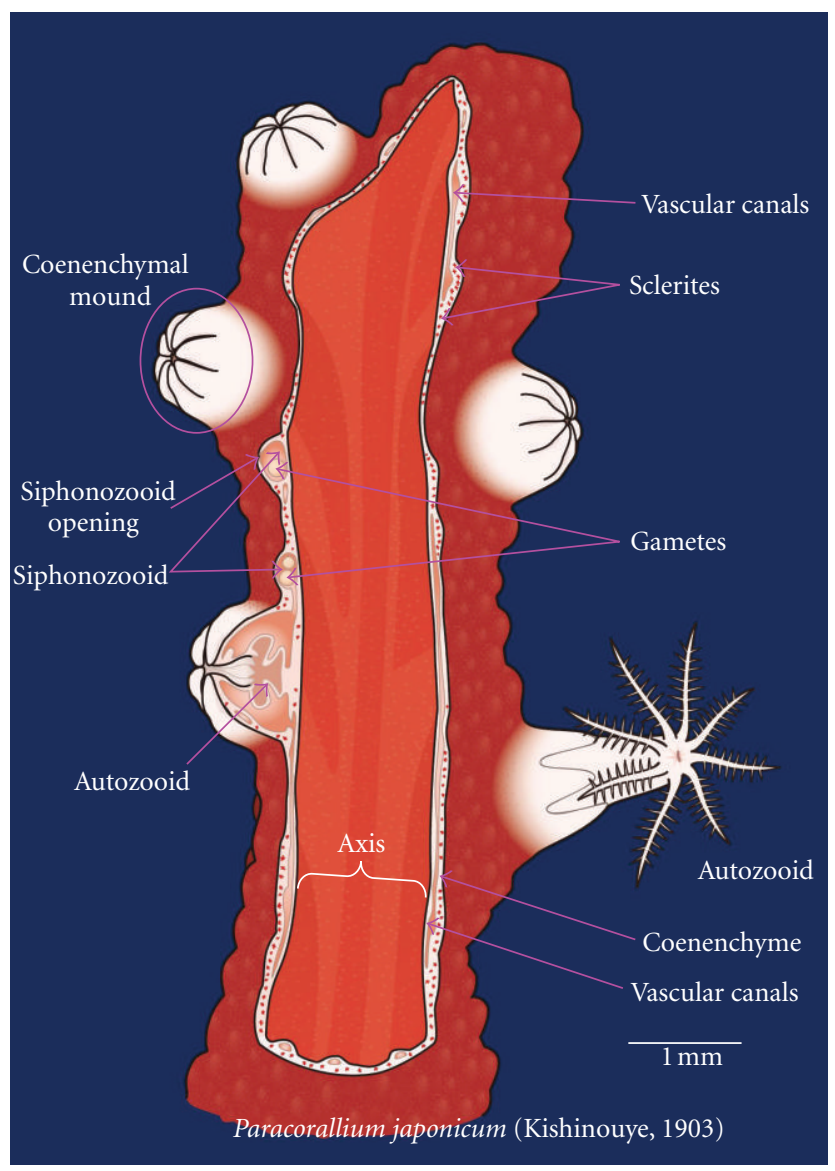

Figure 14: Diagrammatic section through a branchlet of Paracorallium japonicum, showing coenenchyme and axis. The coenenchyme of this species is so thin that canal systems are drawn more simply than in actuality.

on the surface (Figure 17). In transverse sections (Figure 16; bottom), there were openings larger than the marks of sclerites, and in the longitudinal sections (Figure 16; top), openings were oval, elongate, or formed longer canals. Canals averaged $0.095 \mathrm{~mm}$ in width $( \pm 0.018 \mathrm{SD}, n=19)$, and roughly formed two lines along the axis, and, were connected at autozooids and siphonozooids (Figure 16; top).

All autozooids were contracted in the specimens examined. Contracted autozooids were covered by a thin coenenchyme composed of many sclerites (Figure 19; top). They were hemispheric in shape, and we called these "coenenchymal mounds" on the coenenchyme surface (Figure 15). The coenenchymal mounds were almost uniform in shape and size (Figure 15), and their diameter averaged $1.53 \mathrm{~mm}$ $( \pm 0.19 \mathrm{SD}, n=22)$, while height averaged $0.54 \mathrm{~mm}$ $( \pm 0.19 \mathrm{SD}, n=22)$. Autozooids had tentacles, gastric cavities, muscular tissue, and septae. Their gastric cavities were empty. In parts of the tentacles, there were many minute openings that may have been marks of sclerites (Figure 19; top).

Siphonozooids had undeveloped septa, and operculumlike structures were observed inside of the openings (Figure 17). These openings were minute on the surface (Figure 17),

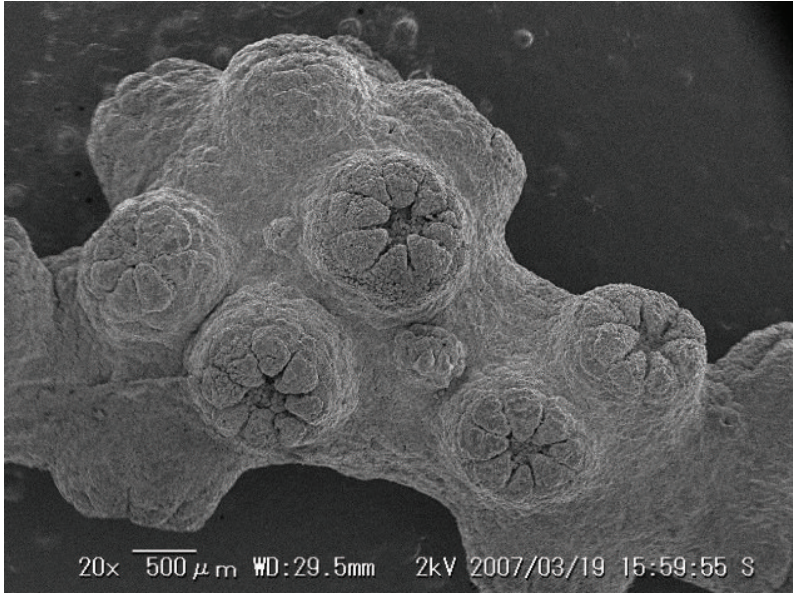

FIGURE 15: SEM image of coenenchyme surface of Corallium elatius; OCA-Cn20060210-029.

with a diameter averaging $0.039 \mathrm{~mm}( \pm 0.010 \mathrm{SD}, n=23)$. The insides of siphonozooids were of various shapes and sizes, and some harbored gonads, and almost all siphonozooids were not mounded on the surface (Figures 16 and 17). Siphonozooid and canal systems could be distinguished by their shapes and the presence of undeveloped septa, however, both siphonozooids and canal systems were generally openings round in shape in the transverse sections. Moreover, attempts to observe septa in more detail with other sections were not successful. Therefore, siphonozooids could not be strictly distinguished from canals in the transverse sections (Figure 16; bottom).

Axial skeletons were decalcified and it was observed that there were large openings at the centers of the colonies in the prepared slides. Axial skeleton cross-sections were oval or rounded (Figure 16; below). At the terminal parts of the branches, no axial skeletons were observed. In SEM examinations, the surface of the axis was unremarkable longitudinally grooved, at approximately $0.27 \mathrm{~mm}$ intervals, and covered with minute tubercles ornamented with thorny projections (Figure 20; bottom). There were no pits underneath autozooids in the specimens examined in this study.

Figure 21 shows a diagram of $C$. elatius based on the results of these observations and measurements.

3.2.3. Corallium konojoi (Japanese Name: Shiro-Sango). This species had a very smooth coenenchyme surface (Figure $22)$, averaging $0.83 \mathrm{~mm}( \pm 0.32 \mathrm{SD}, n=43)$ in thickness (Figure 23; top), and the coenenchyme was significantly thicker on the side with autozooids, averaging $0.94 \mathrm{~mm}$ in thickness $( \pm 0.34 \mathrm{SD}, n=20)$, compared to the posterior (without autozooids) side, which averaged $0.74 \mathrm{~mm}$ in thickness $( \pm 0.28 \mathrm{SD}, n=23)$ ( $t$-test, $P<0.05)$. The coenenchyme was hypertrophic at the terminals of twigs (Figure 23; bottom). Many minute openings were observed in the coenenchyme in the histological sections, and they were approximately $0.06 \mathrm{~mm}$ in diameter (Figure 24). In SEM examinations, sclerites of the specimens were approximately 0.05-0.07 mm long (Figure 25), and, therefore, we concluded 

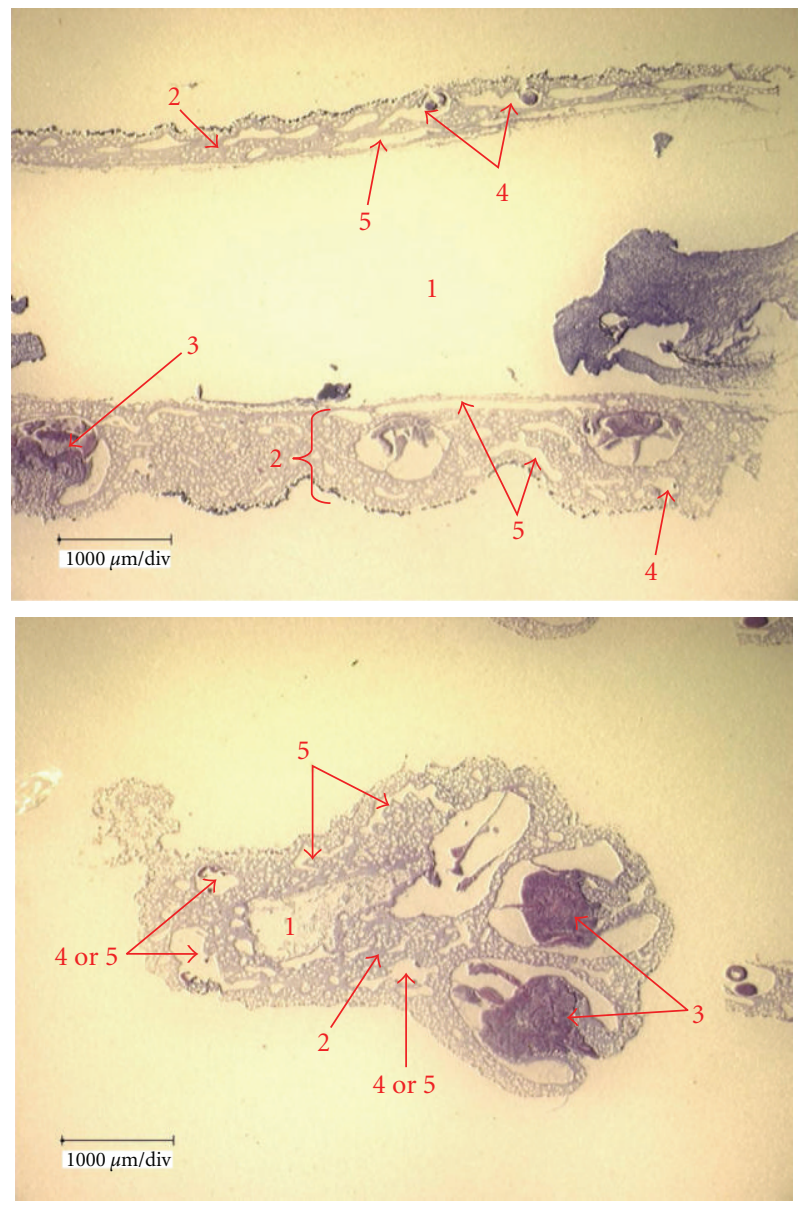

Figure 16: Histological sections of Corallium elatius; longitudinal section of OCA-Cn20050606-008 (above), and transversal section of OCA-Cn20050620-021 (below). 1: axis, 2: coenenchyme, 3: autozooid, 4: siphonozooid, 5: vascular canals.

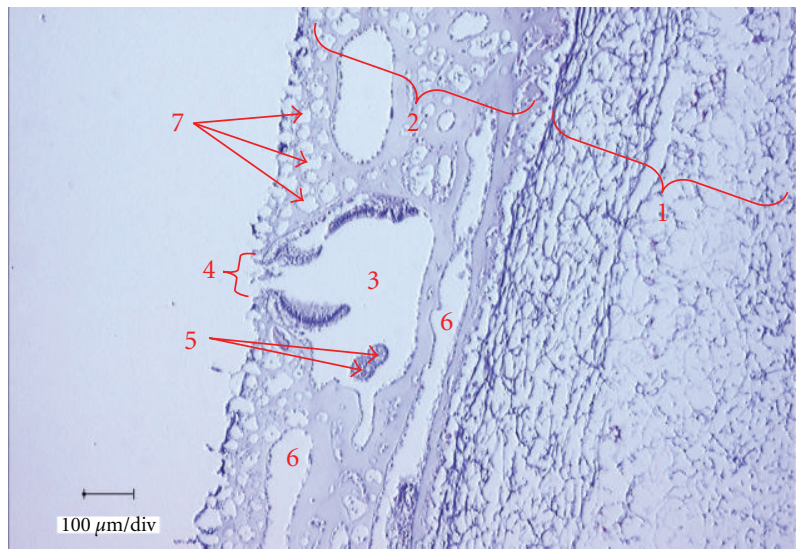

Figure 17: Histological section of Corallium elatius; OCACn20071202-007. 1: axis, 2: coenenchyme, 3: siphonozooid, 4: siphonozood's opening, 5: gamete (sperm sac), 6: vascular canals, 7: sclerite's openings.

that these openings were decalcified sclerites. The sclerites filling up the coenenchyme were distributed more densely on the surface side than on the axial side. In the transverse sections (Figure 23; bottom), larger openings were more

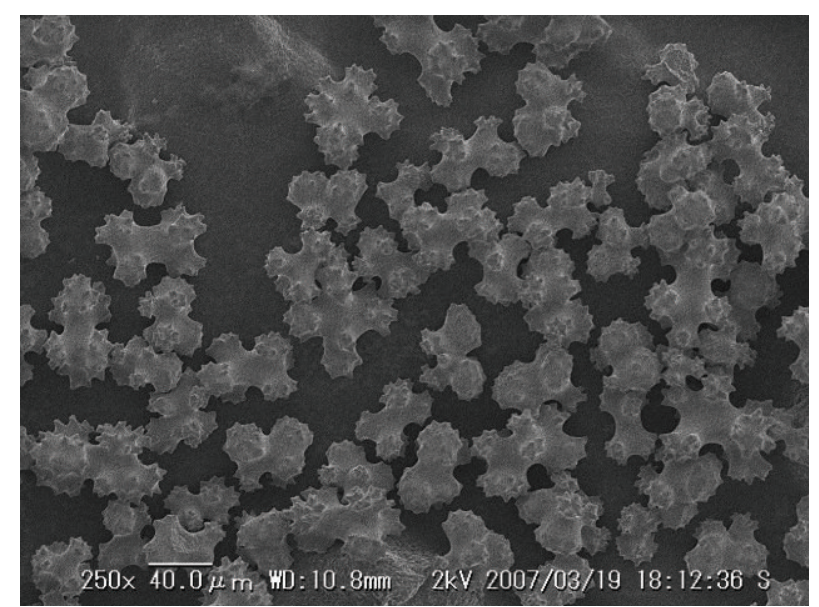

FIGURE 18: SEM image of sclerites of Corallium elatius; OCACn20060213-037.

often observed than sclerites, and in the longitudinal section (Figure 23; top, Figure 24), openings looked oval or elongate or formed longer canals, averaging $0.13 \mathrm{~mm}$ in width $( \pm 0.04 \mathrm{SD}, n=20)$, parallel with the axis. They connected 

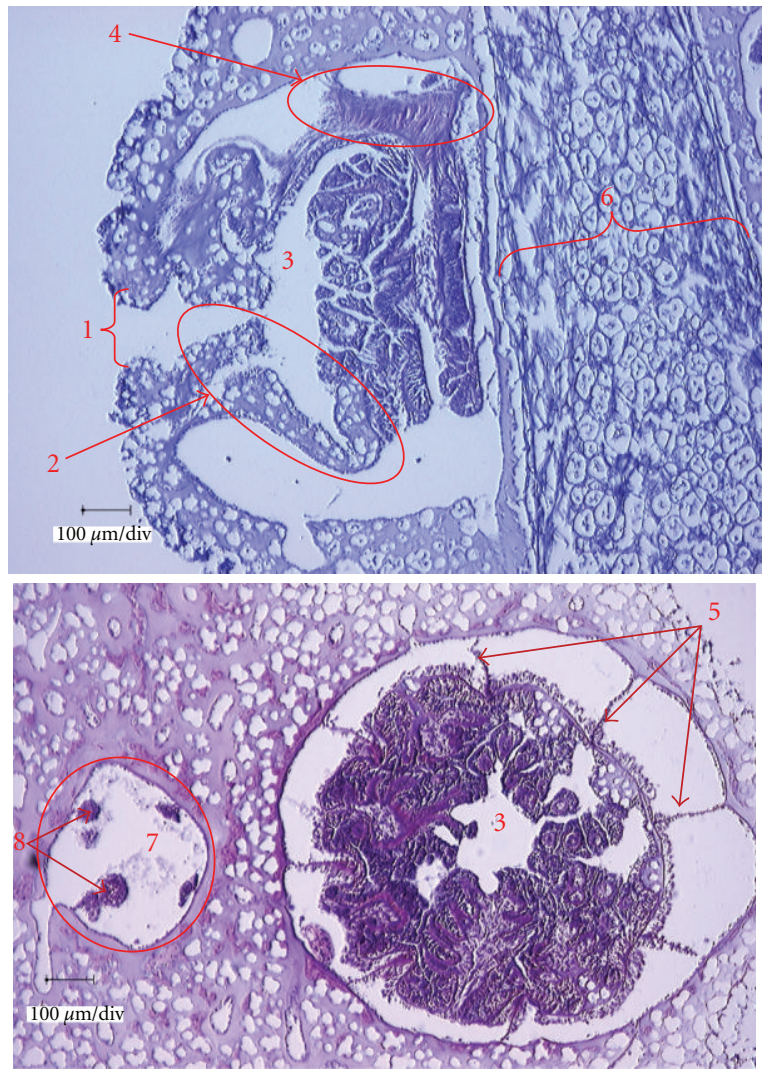

FIGURE 19: Longitudinal section (above; OCA-Cn20090413-047) and transverse section (below; OCA-Cn20060214-041) of autozooid of Corallium elatius. 1: mouth opening, 2: tentacle, 3: gastric cavity, 4: muscular tissue, 5: septum, 6: axis, 7: siphonozooid, 8: gamete (sperm sac).

to organizations of autozooids and siphonozooids, and to two or three layers in the thick coenenchyme (Figure 23; top, Figure 24).

All autozooids were contracted in the specimens examined. Contracted autozooids were covered by coenenchymal mounds that were almost uniform in shape and size (Figures 22 and 23), and these mounds formed low hemispheres covered by a thick coenenchyme composed of many sclerites (Figure 23, Figure 26; bottom). Diameter of coenenchymal mounds averaged $1.74 \mathrm{~mm}( \pm 0.30 \mathrm{SD}, n=22)$, and height averaged $0.80 \mathrm{~mm}( \pm 0.32 \mathrm{SD}, n=13)$. Autozooids were observed to have tentacles, gastric cavities and mesenteries. However, their gastric cavities were found to be empty. In part of the tentacles, there were many minute openings, similar to as seen in the coenenchyme (Figure 26; bottom). These may have been marks of the sclerites.

Siphonozooids had undeveloped septa, and operculumlike structures inside the openings (Figure 24). The openings were minute on the surface (Figure 24), averaging $0.045 \mathrm{~mm}$ in diameter $( \pm 0.012 \mathrm{SD}, n=16)$. The insides of siphonozooids were of various shapes and sizes, and some harbored gonads (Figure 24). No siphonozooids formed hemispheres and some siphonozooids were distributed near the core
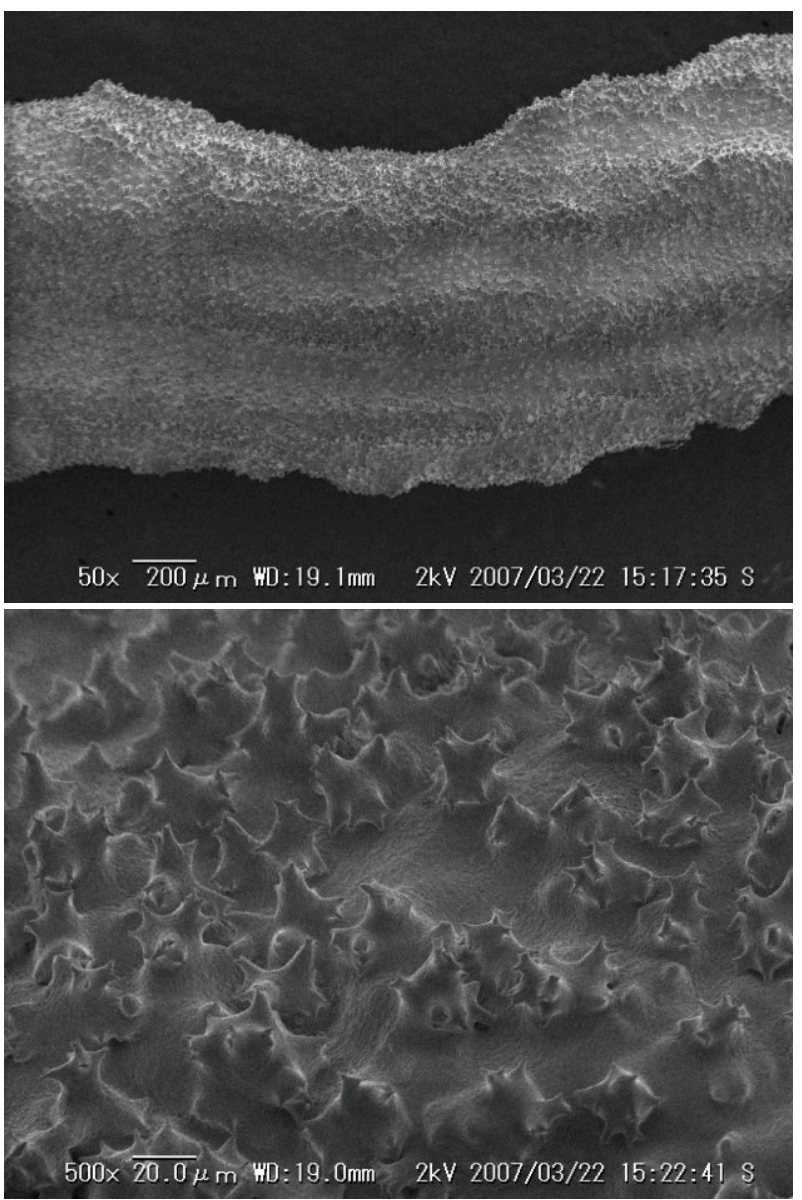

FIgure 20: SEM image of axis surface of Corallium elatius; OCACn20050815-001.

part of the coenenchyme. Some siphonozooids could not be distinguished clearly from canals in the transverse sections.

Axial skeletons were decalcified and were found to have large openings at the centers of colonies (Figure 23). Transverse sections of axes were oval or rounded (Figure 23; bottom). At the terminal parts of the branches, there was no axial skeleton. In SEM examinations, the surface of the axis was faintly longitudinally grooved (Figure 27; top), at approximately $0.5 \mathrm{~mm}$ intervals, and covered with minute tubercles ornamented with thorny projections (Figure 27; bottom). Some specimens were incompletely decalcified, and some stripes like growth rings present in transverse sections were found (Figure 28).

In one specimen, a commensal animal (Platyhelminthes?) was observed in the coenenchyme (Figure 29). However, no other organisms were observed in these specimens.

Figure 30 shows a diagram of $C$. konojoi based on the results of observations and measurements.

\section{Discussion}

The only report of histological examination of Japanese precious corals was published in more than 100 years ago $[7,8]$. Although the observations in this study were carried out by 


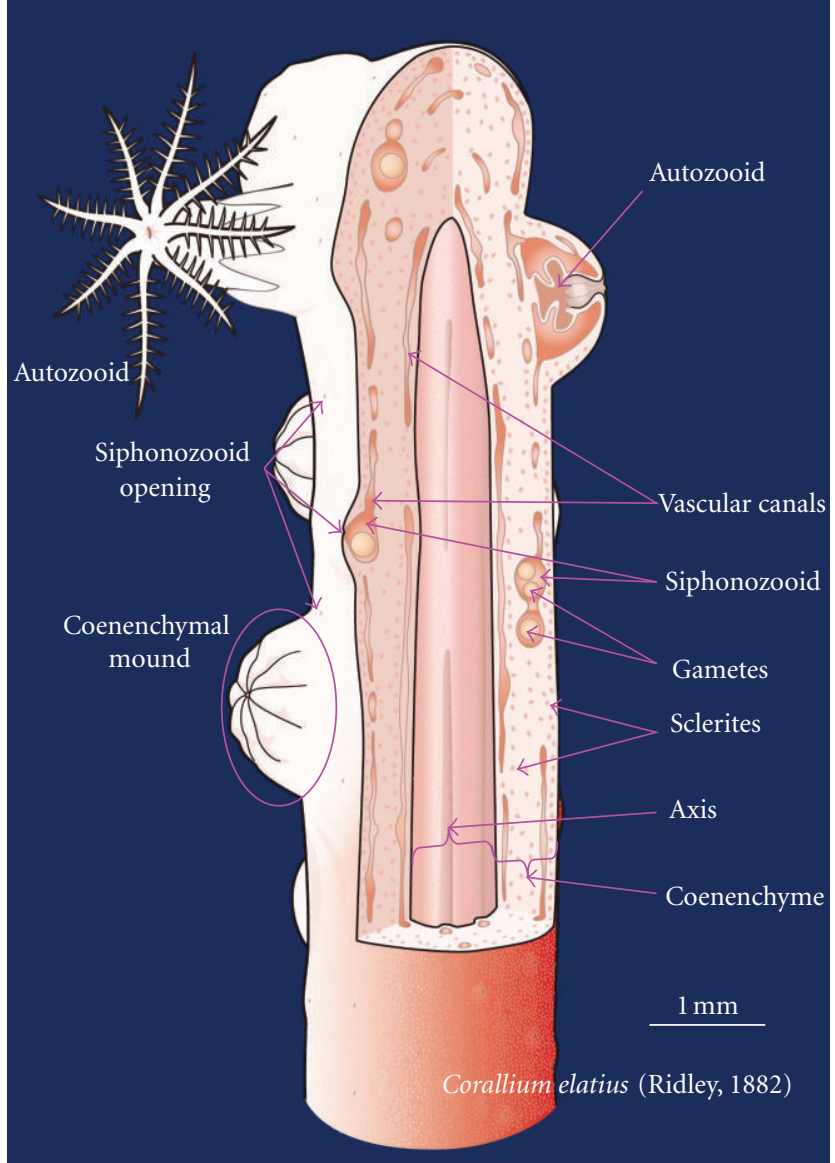

Figure 21: Diagrammatic section through a branchlet of Corallium elatius, showing coenenchyme and axis.

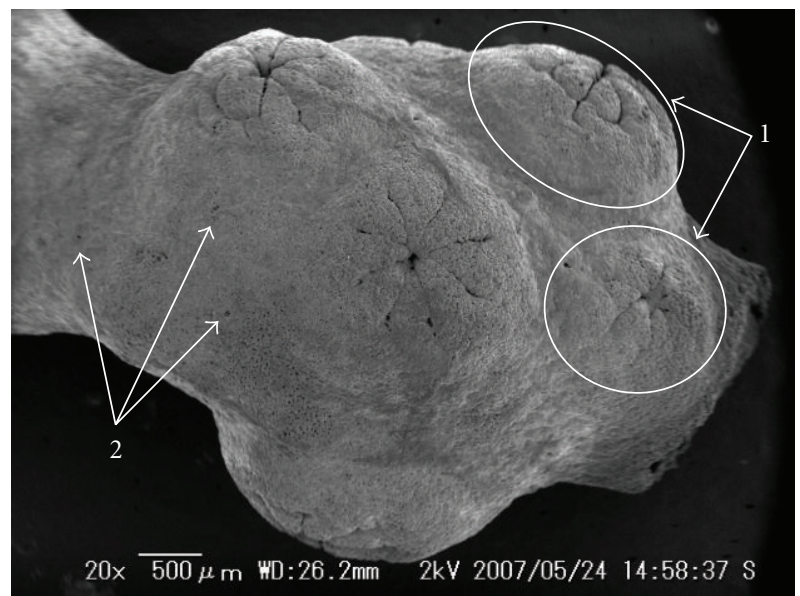

FIgure 22: SEM image of coenenchyme surface of Corallium konojoi; OCA-Cn20050619-020. 1: coenenchymal mounds, 2: siphonozooid openings.

primitive microscope, Kishinouye gave a very detailed report of the examination with hand-written figures. Kishinouye explained how gonads differentiated in siphonozooids, and that the thin coenenchyme of $P$. japonicum has simple vascular canals, while the thick coenenchyme of $C$. elatius has two layers of canals, and the thick coenenchyme of $C$. konojoi
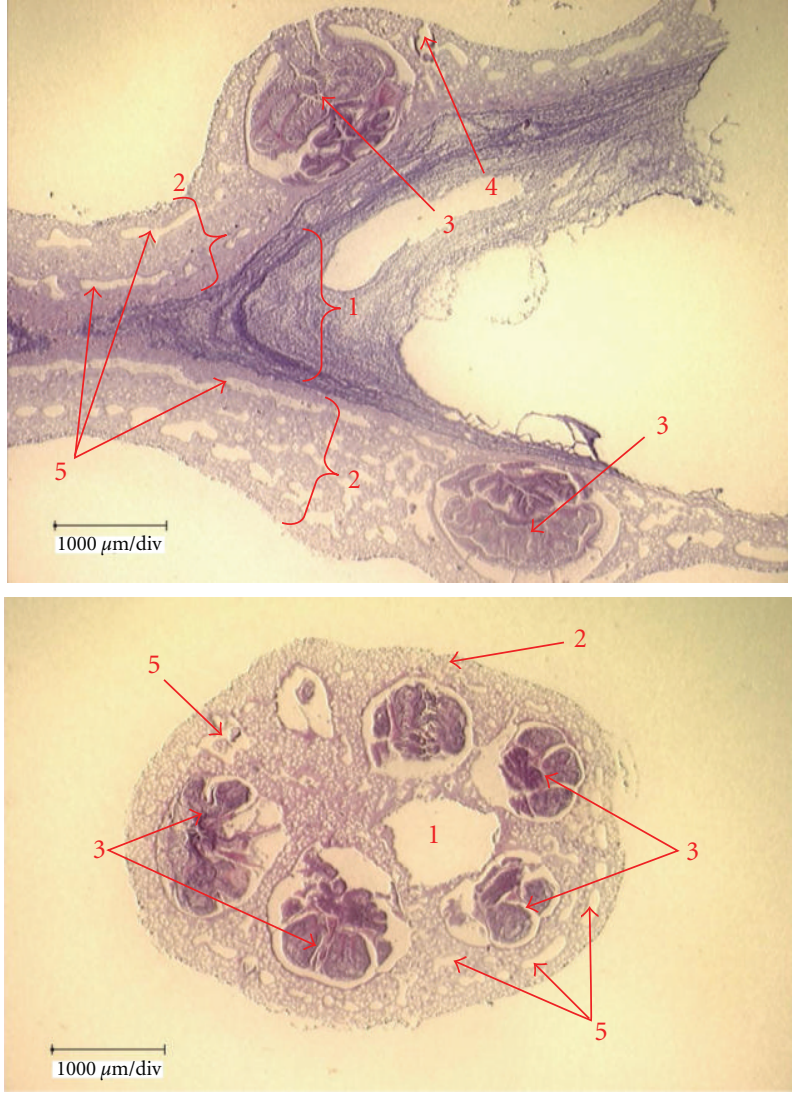

FIgURE 23: Histological sections of Corallium konojoi; longitudinal section of OCA-Cn20090428-038 (above), and transverse section of OCA-Cn20060221-043 (below). 1: axis, 2: coenenchyme, 3: autozooid, 4: siphonozooid, 5: vascular canals.

has a complicated system, with three or more layers of canals $[7,8]$. These results are all same as our observations.

In this study, coenenchyme thicknesses and polyp (autozooid and siphonozooid) sizes were measured by histological sections. This is a more exact method than former studies that measured external morphology. Kishinouye [8] described the thickness of the coenenchyme in three species: "thin" in P. japonicum, and "thick" in C. elatius and $C$. konojoi. In this study, we give a numerical value to the coenenchyme thickness of each species. The coenenchyme of P. japonicum was the thinnest, averaging $0.15 \mathrm{~mm}$ thickness, only $29 \%$ of C. elatius's coenenchyme, and $18 \%$ of $C$. konojoi's coenenchyme. From the results of Kishinouye [7, 8 ] and the present study, thicker coenenchymes tend to have more complicated systems of vascular canals, while species having thinner coenenchymes tend to have rough surfaces with minute warts. These results suggest that there is a relationship between thickness of the coenenchyme and status of the coenenchyme surface. In other words, there is enough space for structures in a thick coenenchyme, and such species have complicated organs in their coenenchymes, but as there is no space in a thin coenenchyme, in these species structures must project out of the surface or beneath the axis. For example, the coenenchyme surface of P. japonicum has distinct coenenchymal mounds covering retracted 


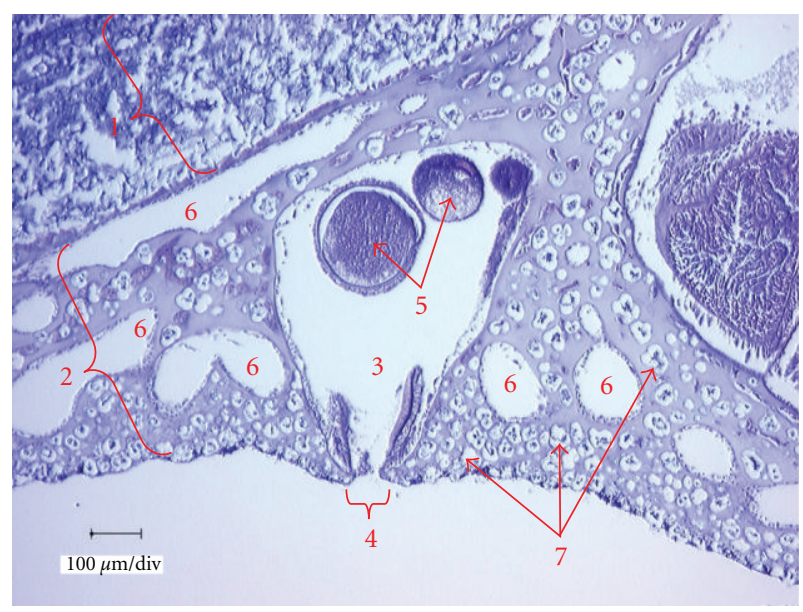

FIgUre 24: Histological section of Corallium konojoi; OCACn20090410-032. 1: axis, 2: coenenchyme, 3: siphonozooid, 4: siphonozood opening, 5: gamete (oocyte), 6: vascular canals, 7: sclerite openings.

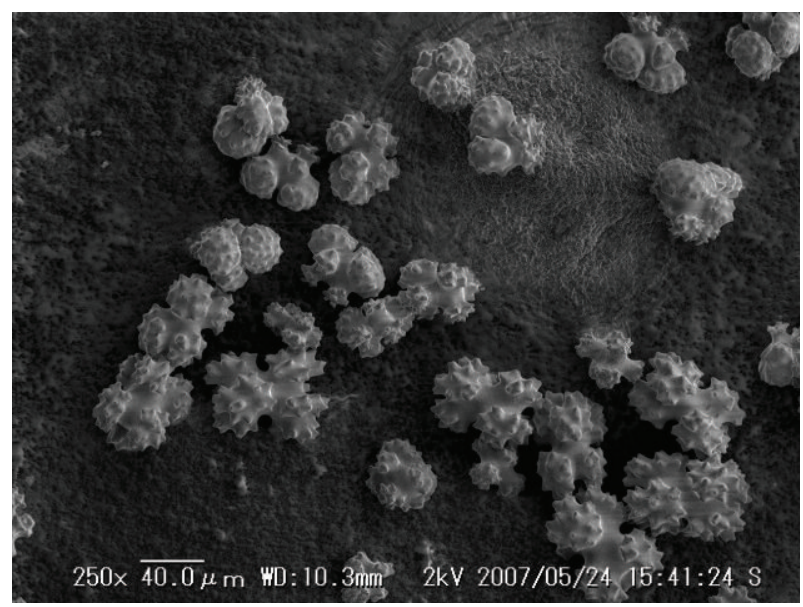

Figure 25: SEM image of sclerites of Corallium konojoi; OCACn20050619-020.

autozooids (Figures 3 and 4), and projections that harbor siphonozooids (Figures 3 and 5). Similarly, axial grooves were only found at the canals in the coenenchyme of $P$. japonicum (Figures 4 and 8). However, colonies of C. konojoi have lower elevated coenenchymal mounds and no projected siphonozooid opening on their thicker coenenchyme (Figure 22). Perhaps in P. japonicum the degrees of the projections' height may show the degrees of differentiation of gonads in siphonozooids.

Muzik and Wainwright [27] includes diagrams of some species of octocorals. In their drawings, scleraxonian specimens have coenenchymes full of sclerites. Viewed in crosssection, the sclerites were closely spaced in the outer layers of the coenenchyme in Subergorgia suberosa, and almost all sclerites were distributed in outer layers in Melithaea ochracea [27]. Grillo et al. [20] show a micrograph of a section of C. rubrum (Figure 3(a)) with sclerites distributed tightly in the epithelium portion of the coenenchyme. We have similar
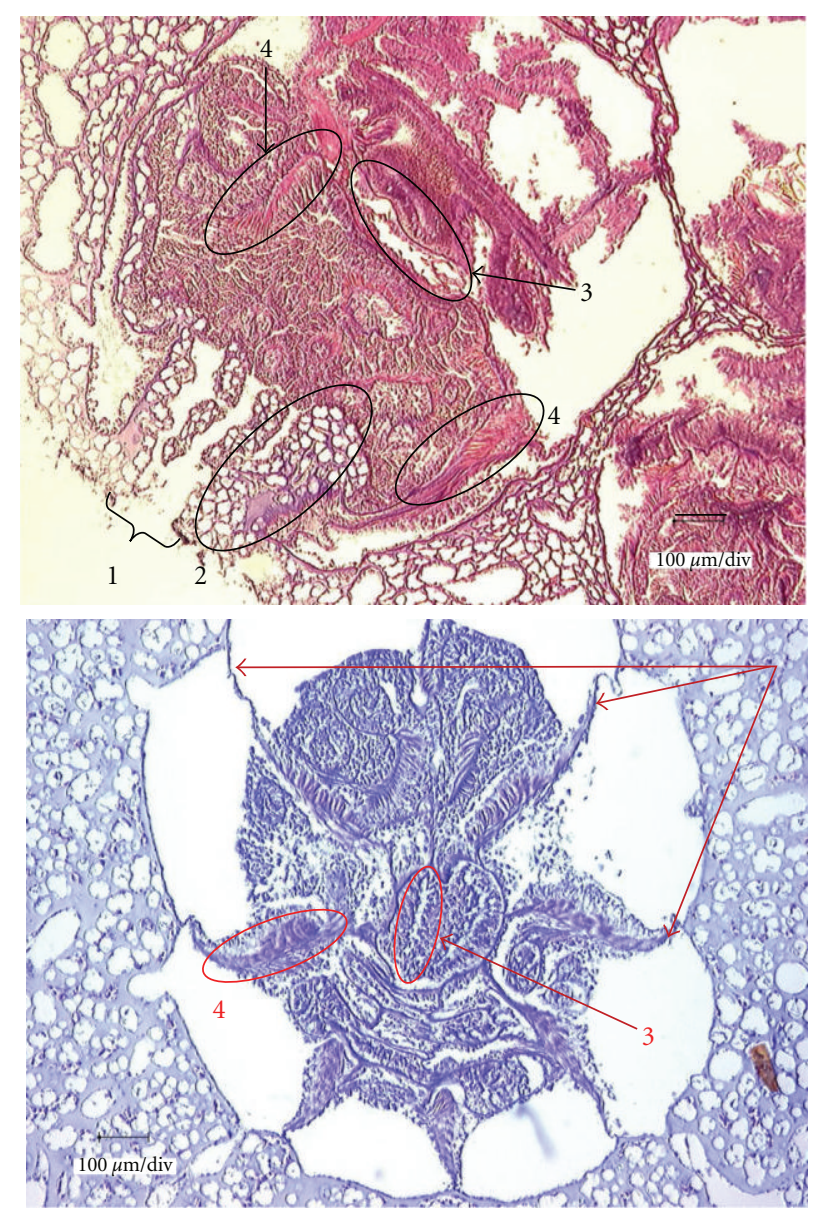

FIGURe 26: The longitudinal section (above; OCA-Cn20081020036) and transverse section (below; OCA-Cn20080205-024) of autozooid of Corallium konojoi. 1: mouth opening, 2: tentacle, 3: gastric cavity, 4: muscular tissue, 5: septum.

results in this study; the sclerites of the three species tended to concentrate in the outer layers of coenenchyme (Figures 5,17 , and 24 ). This may be a defensive strategy. Generally, there are canal systems in inner layers of coenenchyme in Alcyonarian species with hard axes (e.g., [27-30]), and we also found vascular canals in the coenenchyme of examined specimens. The corals may need free space for canals in the inner layers of the coenenchyme and also may need higher densities of sclerites in outer layers of their coenenchyme.

The three species examined this study have been kept successfully in captivity for more than two years at Okinawa Churaumi Aquarium and autozooids were shown to capture frozen copepods in the tank [16]. Thus, we expected to find prey in gastric cavities of autozooids. However, in this study, the gastric cavities we examined were generally empty. In a study on the Mediterranean precious coral, C. rubrum, specimens' guts contained mainly detrital particulate organic matter, as well as crustacean fragments, copepods, invertebrate eggs, and phytoplankton [35]. Furthermore, Allemand [36] reported that C. rubrum can feed in two ways; it either preys on tiny plankton using its tentacles, or absorbs dissolved organic matter from the sea water. In the field, the 

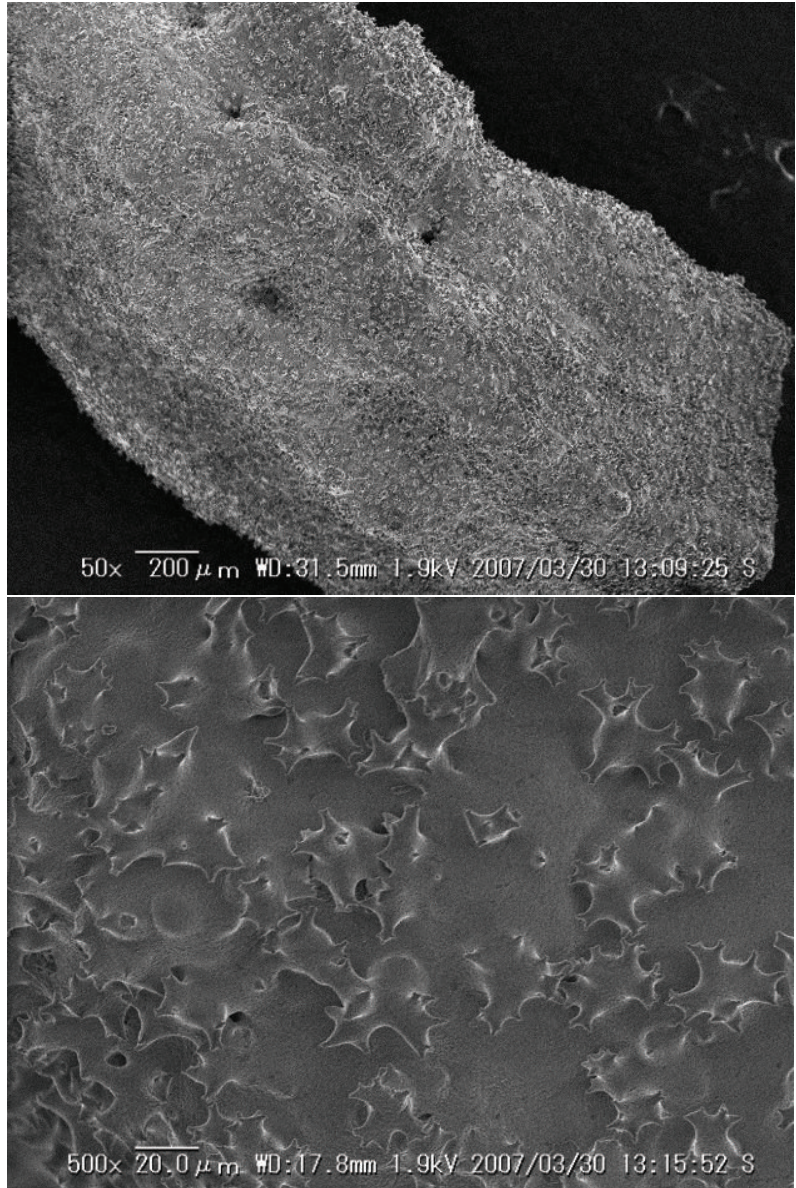

Figure 27: SEM image of axis surface of Corallium konojoi; OCACn20060111-047.

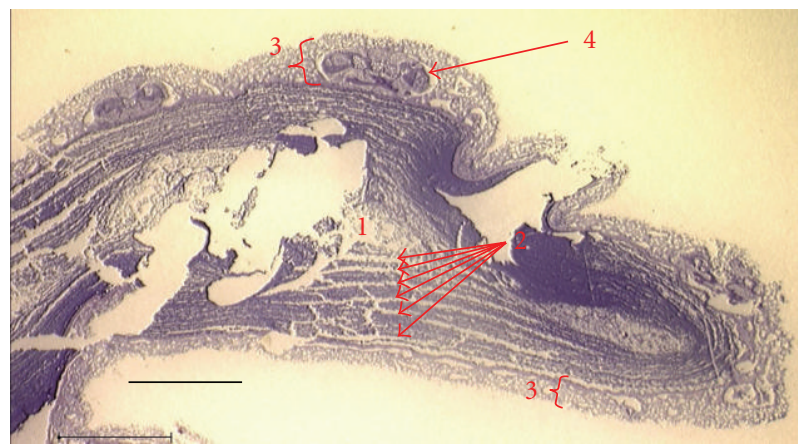

FIGURE 28: Longitudinal section of Corallium konojoi; OCACn20071106-006. 1: center of the axis, 2: growth rings, 3: coenenchyme, 4: autozooid. Scale bar is $1.0 \mathrm{~mm}$.

Japanese species examined in this study may mainly ingest suspended organic matter or protein such as marine snow, or their gastric organ may be able to digest items relatively quickly.

Undeveloped septa in the siphonozooids of Japanese precious corals were observed by Kishinouye [7, 8], and we also observed septa in this study. There are also undeveloped

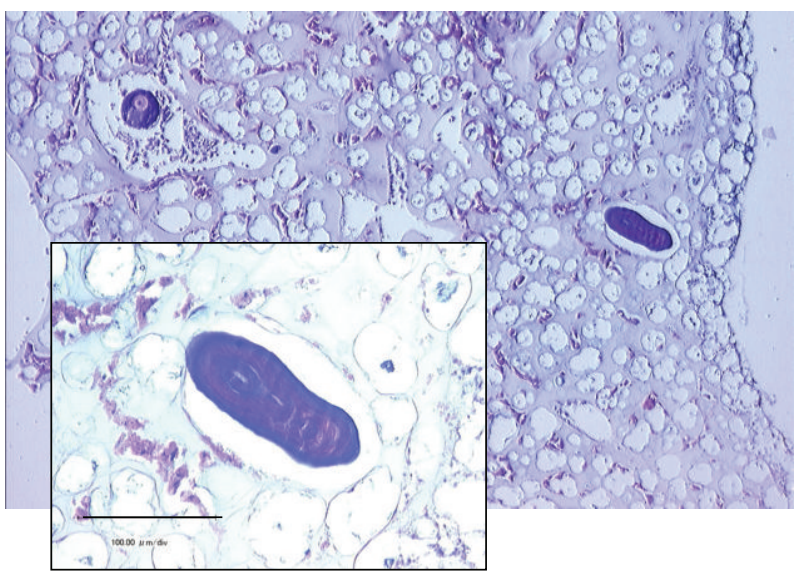

Figure 29: A commensal animal burrowed into the coenenchyme of Corallium konojoi; OCA-Cn20090505-041. Scale bar is $0.1 \mathrm{~mm}$.

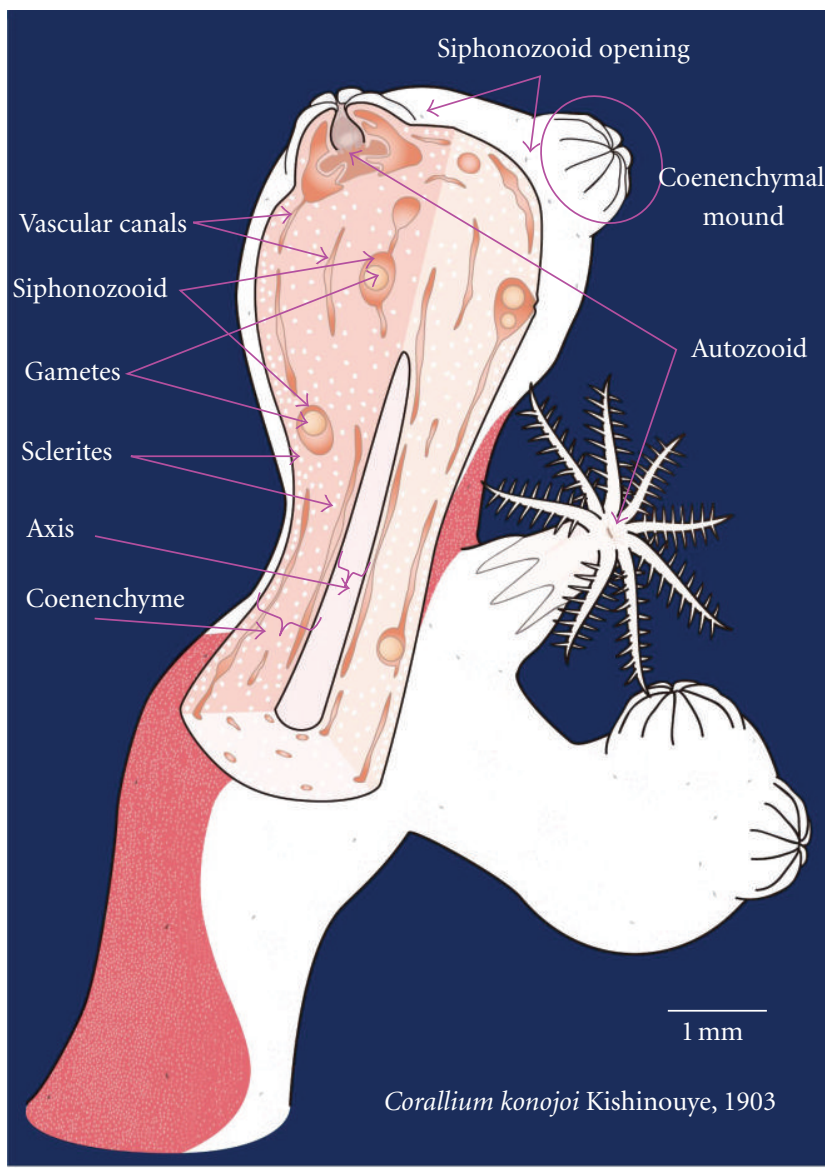

FIgURE 30: Diagrammatic section through a branchlet of Corallium konojoi, showing coenenchyme and axis.

septa in siphonozooids of C. bathyrubrum, an Atlantic species [21]. Additionally, other structures were observed in the siphonozooids. These structures were present at the inner sides around the openings of siphonozooids (Figures 5, 17, and 24). Although we could not identify the function(s) of these structures, they may be inner operculum that regulates 
the opening size of siphonozooids. Generally, the autozooids of Coralliidae corals multiply asexually by budding, and it is also possible that these structures are juvenile autozooids. Strictly speaking, siphonozooids and juvenile autozooids cannot be distinguished. Thus, to confirm the function of these structures, it is necessary to examine the budding process of autozooids by histological observation in the future.

Kishinouye [7, 8] reported that in the base part of colonies the coenenchyme was missing and was "attacked" by boring sponges. As well, he found several kinds of bivalves, gastropods, cirripedes, and bryozoans on coral axial skeletons. In the present study, some commensal organisms (mainly polychaetes) were observed only on the colonies of P. japonicum (Figure 10), excepting one possible Platyhelminthes from a single C. konojoi colony (Figure 29). Unfortunately, we could observe only section images of these organisms, and we could not confirm their taxon. Prepared specimens for microscopic observation were only small pieces of whole colonies, but commensals were found at a rate of 21 per 75 P. japonicum specimens (28\% of specimens examined). This suggests that commensal rates may be quite high and that possibly most $P$. japonicum colonies harbor commensals. Bayer [37] reported that polychaete worms lived in the colony, and copepods (family Lamippidae) were found in the gastric cavities of autozooids in C. niobe (Atlantic species), and he included a drawing of "worm tunnel." Similarly, a commensal polychaete, Gorgoniapolynoe ceceilae, was harbored in colonies of C. niobe and C. bayeri (both Atlantic species), also suggesting the existence of species-specific commensal-host relationships [21]. Therefore, it is possible that the commensal polychate associated to $P$. japonicum is an undescribed species. Calcinai et al. [38] described a new species of boring sponge, Alectona sarai, burrowed into the axis of $P$. japonicum. As well, four other species of sponges boring into $C$. elatius axes are known [38]. Additionally, some species of gastropods (Primovula spp.) have been found on precious coral coenenchyme surfaces; Primovula jeanae is associated with P. japonicum and C. elatius, and Primovula shikamai and Primovula luna are associated only to P. japonicum [39]. Iwasaki and Suzuki [13] have suggested that Primovula luna feeds on the coenenchyme of $P$. japonicum. Finally, Reimer et al. [34] described a new genus and species of zoanthid, Corallizoanthus tsukaharai, associated exclusively with P. japonicum, and we observed two such zoanthid specimens in this study (Figures 12 and 13). One zoanthid individual collected in January 2006 had differentiated gonads, but it is impossible to speculate on spawning seasonality of $C$. tsukaharai without additional observations.

In this study, growth rings of the axis skeleton were observed in P. japonicum (Figure 9) and C. konojoi (Figure 28). Iwasaki and Suzuki [13] reported that the growth rates in $P$. japonicum were $0.30-0.50 \mathrm{~mm} /$ year width and $0.26-$ $0.28 \mathrm{~mm} /$ year in C. elatius. However, it is not certain if growth rings are in fact annual rings, but if they are, then rings of both species are narrower than previously reported and the growth of the axes is, therefore, slower than in the Iwasaki and Suzuki [13].
From the above observations, we have produced color diagrams of the three species (Figures 14, 21, and 30) histology. We hope these figures will provide a good foundation for the continued study of precious corals.

\section{Acknowledgments}

The authors would like to thank Professor N. Iwasaki (Rissyo University) who provided information on precious corals collected from mainland Japan. Dr. K. Muzik (Bishop Museum, Hawaii, USA), Mr. Y. Imahara, and Mr. F. Iwase (both Kuroshio Biological Laboratory, Kochi, Japan) shared much useful knowledge about Coralliidae species and other octocorals with us. Three anonymous reviewers helped greatly improve the manuscript. Special thanks are due to Dr. S. Uchida (Former Director of Okinawa Churaumi Aquarium) for management of this research.

\section{References}

[1] S. Kosuge, The CORALS - Captivating and Charming Gift from Neptune, Special publication, no. 2, Institute of Malacology of Tokyo, Tokyo, Japan, 1987.

[2] B. Liverino, The CORALS-Cultural Tourist Itineraries in the South of Italy, Industrial History Series, Analisi, Rome, Italy, 1986.

[3] S. O. Ridley, "On the arrangement of the Coralliidae, with descriptions of new or rare species," Proceedings of the Zoological Society of London, vol. 50, no. 1, pp. 221-234, 1882.

[4] K. Kishinouye, "Honpou san sango no ichi shinshu," Doubutsu Gaku Zasshi, vol. 14, no. 4, pp. 623-626, 1902 (Japanese).

[5] K. Kishinouye, "Preliminary note on the Coralliidae of Japan," Zoologischer Anzeiger, vol. 26, no. 705, pp. 623-626, 1903.

[6] K. Kishinouye, "Honpou san no sango," Doubutsu Gaku Zasshi, vol. 15, pp. 103-106, 1903 (Japanese).

[7] K. Kishinouye, "Sango no kenkyu," Suisan Chosa Hokoku, vol. 14, no. 1, pp. 1-31, 1904 (Japanese).

[8] K. Kishinouye, "Notes on the natural history of corals," Journal of Imperial Fishery Bureau, vol. 14, no. 1, pp. 1-32, 1904.

[9] F. M. Bayer, "Descriptions and redescriptions of the Hawaiian octocorals collected by the U.S. Fish Commission steamer, "Albatross" (2. Gorgonacea: Scleraxonia)," Pacific Science, vol. 10, no. 1, pp. 67-95, 1956.

[10] F. M. Bayer and S. D. Cairns, "A new genus of the scleraxonian family Coralliidae (Octocorallia: Gorgonacea)," Proceedings of the Biological Society of Washington, vol. 116, no. 1, pp. 222228, 2003.

[11] M. Nonaka and K. Muzik, "Jewels of the deep sea-precious corals," in Proceedings of the International Symposium-Into the Unknown, Researching Mysterious Deep-sea Animals, S. Uchida, Ed., pp. 84-127, Okinawa Churaumi Aquarium, Okinawa, Japan, February 2007, 2010.

[12] R. W. Grigg, "Distribution and abundance of precious corals in Hawaii," in Proceedings of the 2nd International Coral Reef Symposium, pp. 235-340, Great Barrier Reef Committee, Queensland, Australia, 1974.

[13] N. Iwasaki and T. Suzuki, "Biology of precious coral," in $A$ Biohistory of Precious Coral, N. Iwasaki, Ed., pp. 3-25, Tokai University Press, 2010.

[14] Y. Ueno, K. Tashima, M. Yamaguchi, M. Kashizaki, and K. Myojin, "Culture of precious corals, Corallium japonicum 
Kishinouye in aquaria," Precious Corals \& Octocoral Research, vol. 1, pp. 30-38, 1993.

[15] F. Iwase, "Aka-sango shiiku tenmatsuki," Marine Pavilion, vol. 24, no. 4, pp. 20-21, 1995 (Japanese).

[16] M. Nonaka, K. Muzik, and S. Uchida, "Culture, study and display of precious corals," in Proceedings of the 10th International Coral Reef Symposium, pp. 1821-1831, Japanese Coral Reef Society, Tokyo, Japan, 2006.

[17] N. Iwasaki, A Biohistory of Precious Coral, Tokai University Press, 2010.

[18] H. D. Lacaze-Duthiers, "On the formation of coral (Corallium rubrum)," Quarterly Journal Science, vol. 1, pp. 614-623, 1864.

[19] S. J. Hickson, "On a new species of Corallium from Timor," Proceedings of the Meeting of Saturday September, vol. 30, pp. 268-271, 1905.

[20] M. C. Grillo, W. M. Goldberg, and D. Allemand, "Skeleton and sclerite formation in the precious red coral Corallium rubrum," Marine Biology, vol. 117, no. 1, pp. 119-128, 1993.

[21] A. Simpson and L. Watling, "Precious corals (Coralliidae) from north-western Atlantic Seamounts," Journal of the Marine Biological Association of the United Kingdom, vol. 91, no. 2, pp. 369-382, 2011.

[22] J. Debreuil, S. Tambutte, D. Zoccola et al., "Specific organic matrix characteristics in skeletons of Corallium species," Marine Biology, vol. 158, pp. 2765-2774, 2011.

[23] G. C. Williams and S. D. Cairns, "Systematic list of valid octocoral genera," 2009 http://researcharchive.calacademy.org/ research/izg/orc_home.html.

[24] M. Grasshoff, "The shallow water gorgonians of New Caledonia and adjacent islands (Coelenterata, Octocorallia)," Senckenbergiana Biologica, vol. 78, no. 1-2, pp. 1-121, 1999.

[25] K. Kinoshita, "On the Keroeididae, a new family of Gorgonacea, and some notes on the Suberogorgiidae," Annotationes Zoologicae Japonenses, vol. 7, no. 4, pp. 223-230, 1910.

[26] F. M. Bayer, "A new isidid octocoral (Anthozoa: Gorgonacea) from New Caledonia, with descriptions of other new species from elsewhere in the Pacific Ocean," Proceedings of the Biological Society of Washington, vol. 103, no. 1, pp. 205-228, 1996.

[27] K. Muzik and S. Wainwright, "Morphology and habitat of five Fijian sea fans," Bulletin of Marine Science, vol. 27, no. 2, pp. 308-337, 1977.

[28] F. M. Bayer, "Studies on the anatomy and histology of Plexaura homomalla in Florida," in Prostaglandins from Plexaura homomalla: Ecology, Utilization and Conservation of a Major Medical Marine Resource a Symposium, F. M. Bayer and A. J. Weinheimer, Eds., Studies in Tropical Oceanography, no. 12, pp. 62-100, 1974.

[29] F. M. Bayer, M. Grasshoff, and J. Verseveldt, Illustrated Trilingual Glossary of Morphological and Anatomical Terms Applied to Octocorallia, E. J. Brill/Dr. W. Backhuys, 1983.

[30] M. Grasshoff and G. Bargibant, Coral Reef Gorgonians of New Caledonia, IRD, 2001

[31] M. Nonaka and K. Muzik, "Recent harvest records of commercially valuable precious corals in the Ryukyu Archipelago," Marine Ecology Progress Series, vol. 397, pp. 269-278, 2009.

[32] M. Nonaka, K. Muzik, and N. Iwasaki, "Descriptions of two new species and designation of three neotypes of Japanese Coralliidae from recently discovered specimens that were collected by Kishinouye, introducing a statistical approach to sclerite abundance and size," Zootaxa, vol. 3428, pp. 1-67, 2012.

[33] C. B. Castro, C. M. Thiago, and M. S. Medeiros, "First record of the family Coralliidae (Cnidaria: Anthozoa: Octocorallia) from the Western South Atlantic, with a description of Corallium medea Bayer," Zootaxa, vol. 323, pp. 1-8, 2003.

[34] J. D. Reimer, M. Nonaka, F. Sinniger, and F. Iwase, "Morphological and molecular characterization of a new genus and new species of parazoanthid (Anthozoa: Hexacorallia: Zoantharia) associated with Japanese Red Coral," Coral Reefs, vol. 27, no. 4, pp. 935-949, 2008.

[35] G. Tsounis, S. Rossi, J. Laudien et al., "Diet and seasonal prey capture rates in the Mediterranean red coral (Corallium rubrum L.)," Marine Biology, vol. 149, no. 2, pp. 313-325, 2006.

[36] D. Allemand, "The biology and skeletogensis of the Mediterranean red coral," Precious Corals \& Octocoral Research, vol. 2, pp. 19-39, 1993.

[37] F. M. Bayer, "The genus Corallium (Gorgonacea: Scleraxonia) in the Western North Atlantic Ocean," Bulletin of Marine Science of the Gulf and Carivvean, vol. 14, no. 3, pp. 465-478, 1964.

[38] B. Calcinai, C. Cerrano, N. Iwasaki, and G. Bavestrello, "Sponges boring into precious corals: an overview with description of a new species of Alectona (Demospongiae, Alectonidae) and a worldwide identification key for the genus," Marine Ecology, vol. 29, no. 2, pp. 273-279, 2008.

[39] Y. Omi, "A new species of Primovula (Gastropoda: Ovulidae) from Japan," Venus, vol. 66, pp. 11-17, 2007. 

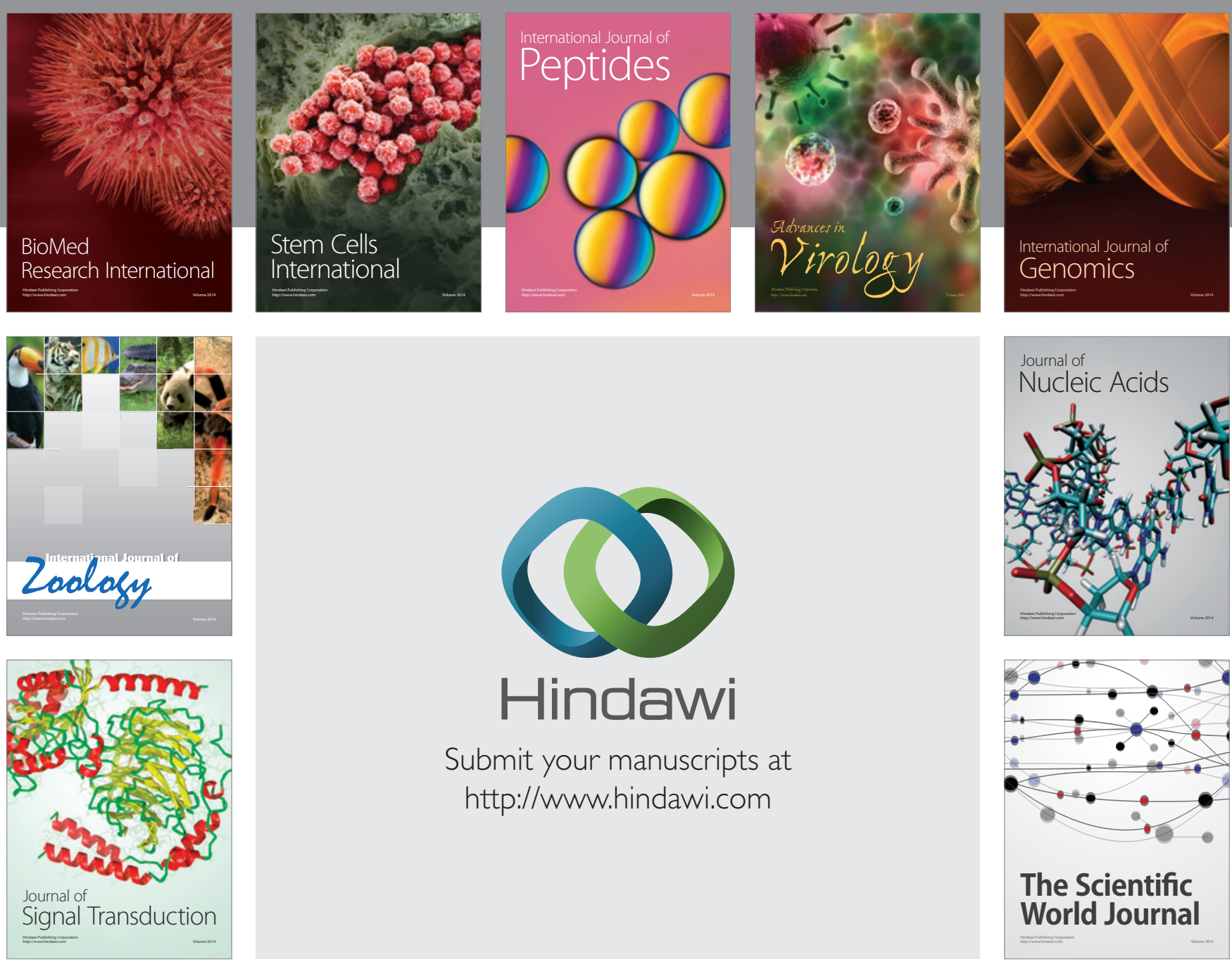

Submit your manuscripts at

http://www.hindawi.com
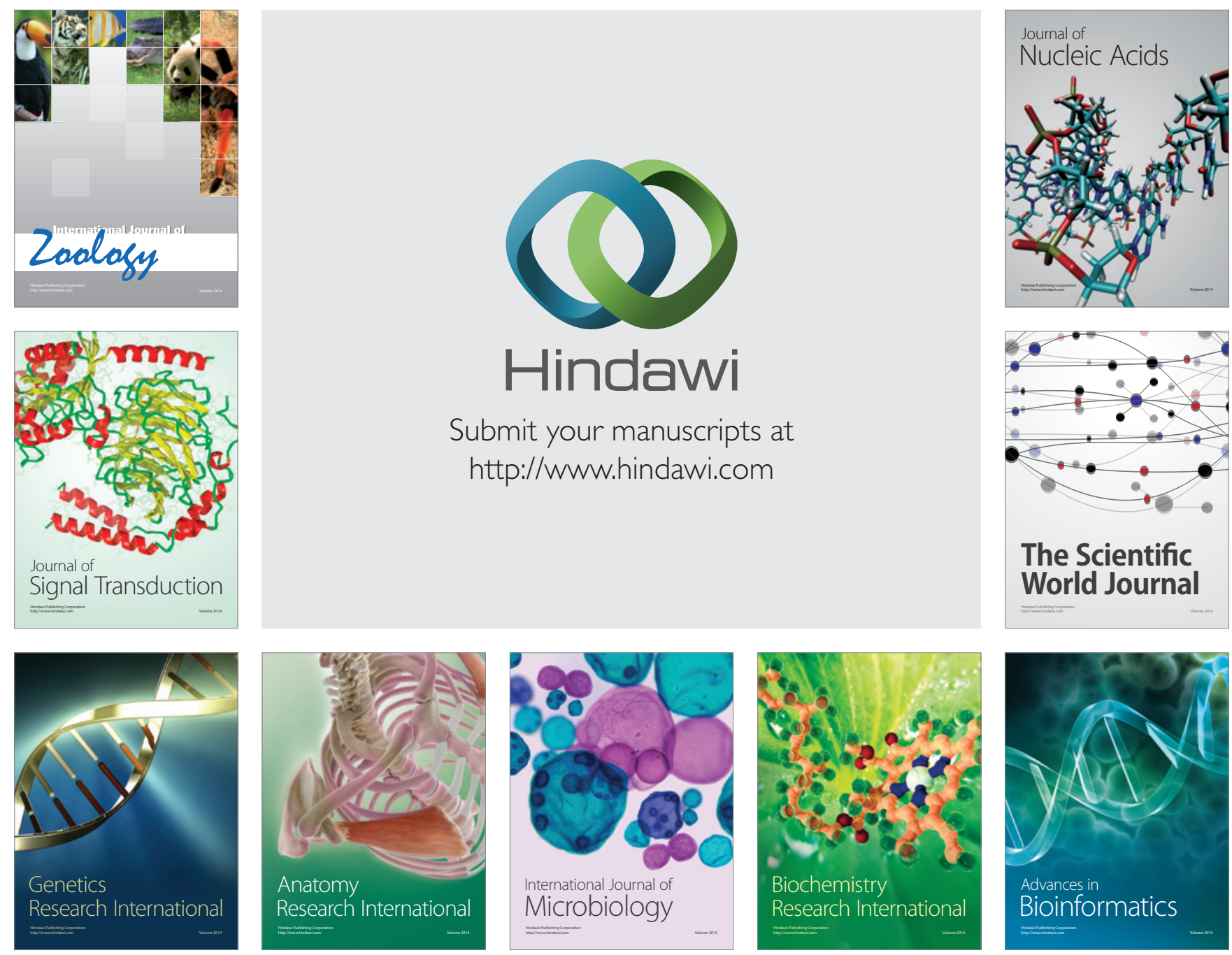

The Scientific World Journal
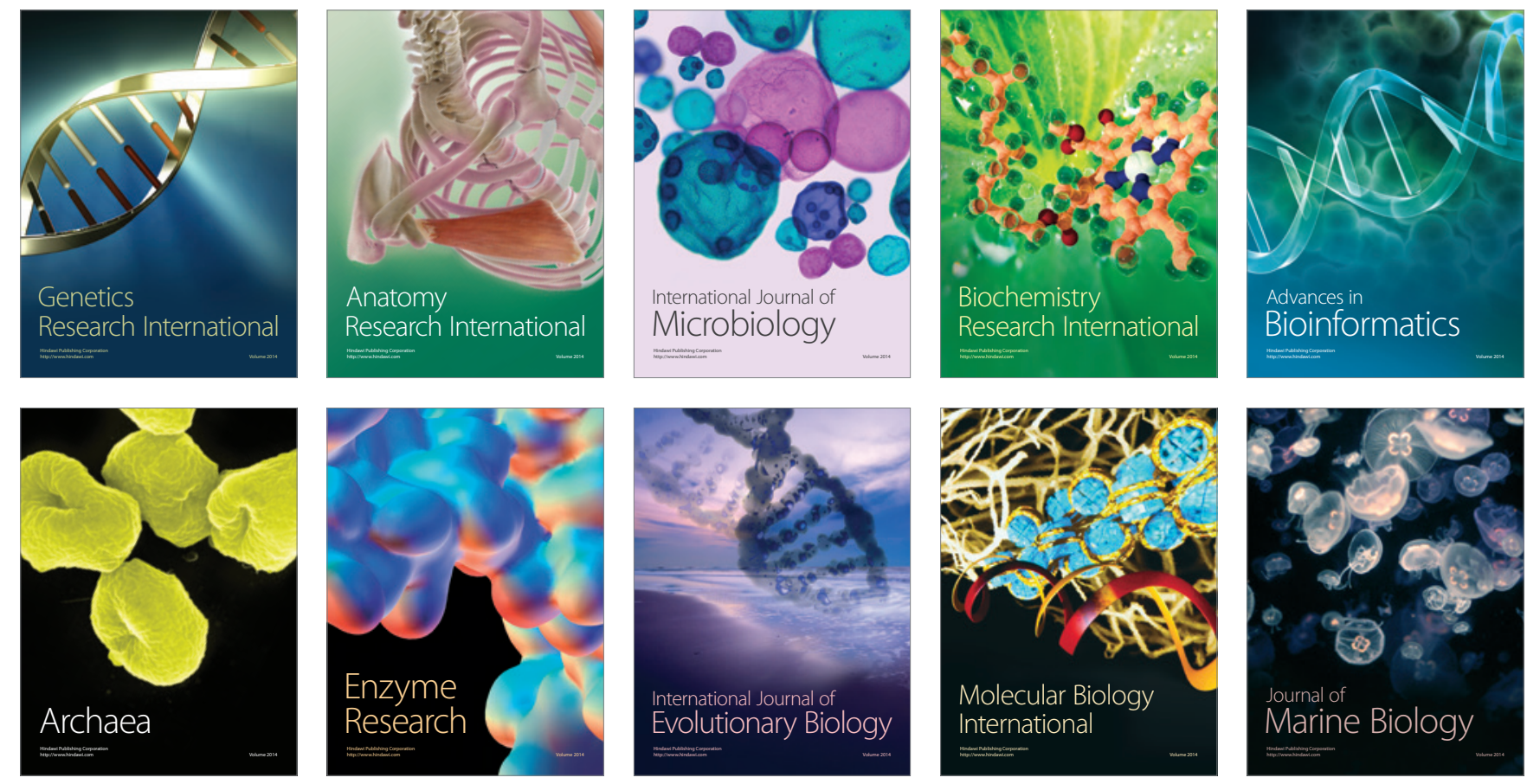